Consulting the community: how customers' needs are reflected in public library collection development policies

by

\title{
Sarah Marion Osborne
}

\begin{abstract}
Submitted to the School of Information Management, Victoria University of Wellington in partial fulfilment of the requirements for the degree of Master of Library and Information Studies
\end{abstract}

February 2004

$\mathrm{h}$

AS741

VUW

- A55

O81

- C 


\section{Acknowledgements}

I should like to thank the public library managers who gave of their time to participate in the interviews which form the basis of this study's findings.

I should also like to thank Professor Gary Gorman for his interest in my work, and for his support throughout all of the stages of this project. 


\title{
VICTORIA UNIVERSITY OF WELLINGTON \\ School of Information Management
}

Master of Library \& Information Studies

IMPORTANT DISCLAIMER

with respect to a MLIS Research Project (LIBR 550)

\section{'Consulting the community: how customers' needs are reflected in public library collection development policies' (hereafter referred to as 'The MLIS Research Project')}

being undertaken by

\author{
Sarah Marion Osborne \\ in partial fulfilment of the requirements of the degree of \\ Master of Library and Information Studies, \\ School of Information Management, \\ Victoria University of Wellington.
}

Topic Commencement: (November 2003)

1. Victoria University of Wellington and its Council, its members, staff, employees, students and agents undertake no duty of care in contract, tort, or otherwise, to users (whether direct or indirect) of the MLIS Research Project and make no warranties or representations of any kind whatsoever in relation to any of its contents.

2. The MLIS Research Project is only made available on the basis that all users of it, whether direct or indirect, must take appropriate legal or other expert advice in relation to their own circumstances and must rely solely on their own judgement and such legal or other expert advice.

3. Under no circumstances will Victoria University of Wellington and its Council, its members, staff, employees, students or agents be liable in any way whatsoever, whether in contract, tort (including negligence), for breach of any statutory or regulatory duty (to the fullest extent permissible by law), or otherwise, to any user (whether direct or indirect) of the MLIS Research Project for any loss or damage whatsoever arising directly or indirectly as a result of the use in any way of the MLIS Research Project.

4. Each exclusion in the clauses of this disclaimer and each protection given by it is to be construed as a separate exclusion applying and surviving even if for any reason any of the exclusions or protections are held inapplicable in any circumstance. 


\section{Contents}

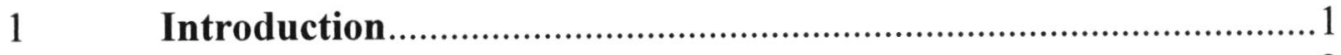

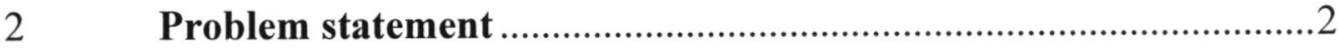

2.1 Local government in New Zealand.............................................

2.2 Public library collection management ..........................................

2.3 Community consultation...........................................................

2.4 Purpose of research................................................................

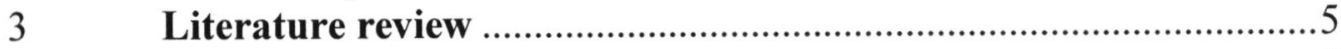

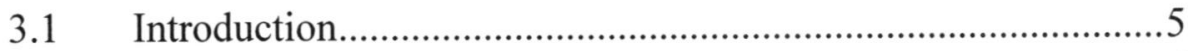

3.2 Definition of terms.................................................................

3.3 Functions of collection development policies ...........................

3.4 The New Zealand situation ......................................................

3.5 Policy formulation ..................................................................

3.6 Community consultation......................................................11

3.7 Community needs analysis ...................................................12

3.8 Strategic planning .................................................................13

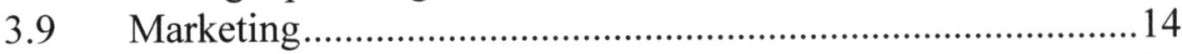

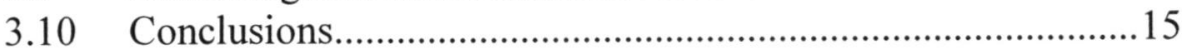

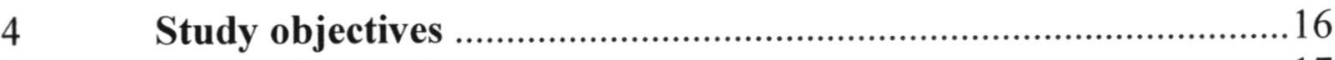

$5 \quad$ Research questions.....................................................................17

5.1 Research problem ................................................................17

5.2 Principal research question .....................................................17

5.3 Research questions and sub-questions.....................................17

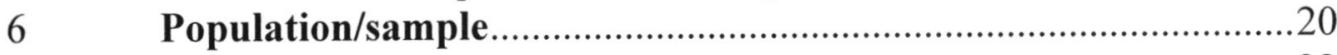

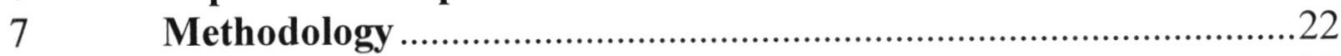

7.1 Qualitative methodology ………………………………......22

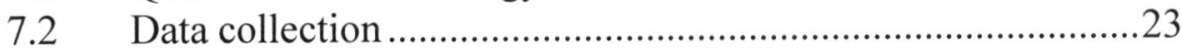

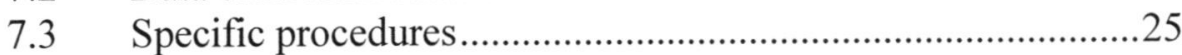

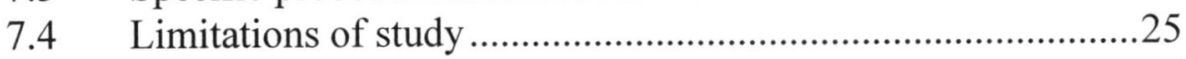

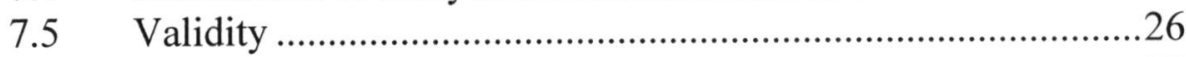

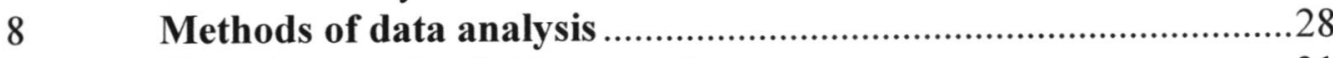

$9 \quad$ Carrying out the field research ………………......................... 31

9.1 Participant contact ………………………………..................31

9.2 Interview schedule .................................................................

9.3 Structure of interviews.............................................................32

9.4 Transcription and verification....................................................33

9.5 Collection development policies................................................34

9.6 Reflective notes .......................................................................

9.7 Advantages and disadvantages of the

10 Carrying out the data analysis.......................................................36

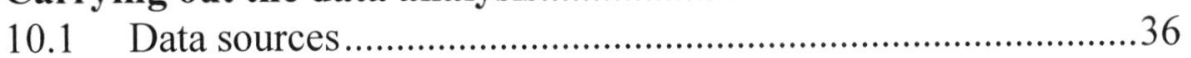

10.2 Development of coding themes .................................................36

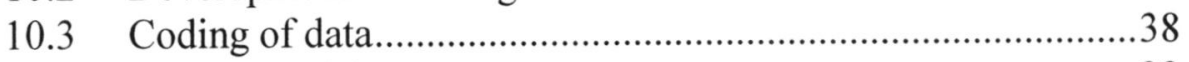

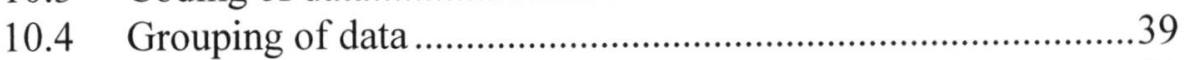

10.5 Preparation of two-way charts .................................................40 
11.1 Methods of community consultation ......................................43

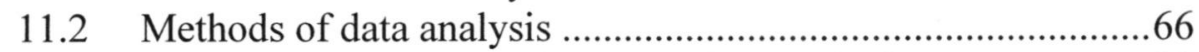

11.3 Comparison of information gathering methods ......................83

11.4 Formal collection development policies ..................................86

11.5 Informal collection development policies ............................93

11.6 Summary of the role played by information-gathering techniques in policy formulation and application....................99

12 Summary and conclusions ........................................................ 102

12.1 Relating the findings to the original conceptualization

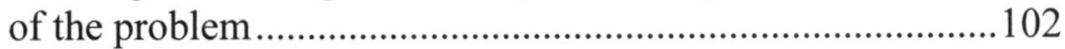

12.2 Recommendations for professional practice..........................106

12.3 Implications for further research, with reference to the limitations of the present study ..............................................116

13 Proposed and actual timetables for the project ..........................118

13.1 Proposed timetable............................................................. 119

13.2 Actual timetable ................................................................. 120

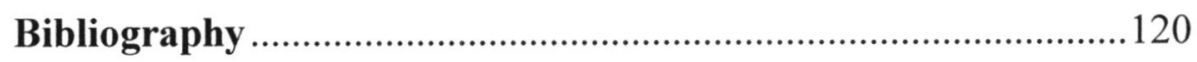

Appendix A: Council websites .........................................................124

Appendix B: Participant information letter .......................................125

Appendix C: Participant consent form ……......................................126

Appendix D: Schedule of interviews ................................................127

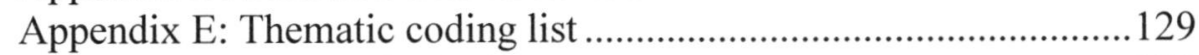

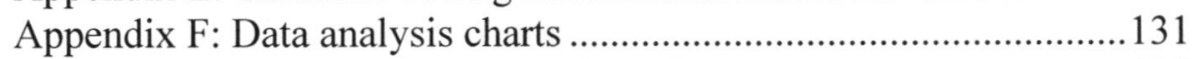

Appendix G: Sample survey questionnaire ......................................133 


\begin{abstract}
This study is an investigation into the methods of community consultation that are undertaken by a sample of New Zealand public library managers during the formulation and application of their libraries' collection development policies. The gathering of information about the needs and wants of customers helps ensure that the public library is practicing responsive collection development. A qualitative methodology is used, consisting of in-depth interviews with a sample of library managers from medium-sized, non-metropolitan public libraries in the lower North Island of New Zealand. Discussion during the interviews centres upon the participants' use of community needs analysis techniques; both "direct" community consultative methods, and "indirect" data analysis methods. The role that formal collection development policies play in the participants' institutions is discussed, together with the relative importance of informal collection development policies, practices and procedures. The study's findings reveal that the process of collection development policy formulation is less well-structured than that described in the literature, and that informal policies, practices and procedures are used to inform day-to-day collection management activities. The application of community consultative techniques by the study participants is less well-developed than descriptions of its use in the international literature.
\end{abstract}

Keywords: Collection development (Libraries); Public libraries - New Zealand; Needs assessment; Community consultation 


\section{Introduction}

"People must want what libraries deliver, or libraries become irrelevant. Librarians need to make sure they know what it is that people want" (Wilson 2000, 81).

As a practitioner with nearly eighteen years' experience of working in the New Zealand public library sector, I am aware that public libraries need to continually change and develop in order to remain relevant to the lives of $21^{\text {st }}$ century citizens.

Public library collections, whether they are in physical or virtual form, lie at the heart of the services offered by the public library.

Responsive collection management practices need to involve consultative processes during the formulation and application of collection development policies. This study intends to focus on the methods that may have been used by a sample of New Zealand public library managers to develop policies that ensure the relevance of their collections to their customers' needs. 


\section{Problem statement}

\subsection{Local government in New Zealand}

The provision of public library services throughout New Zealand is not a mandatory activity for territorial local authorities, but is regarded as a core activity because of the contribution that public libraries make to the wellbeing of the communities they serve.

The New Zealand Local Government Act 2002, which passed into law on 1 July 2003, requires that local authorities obtain the views of their constituents during the course of the decision-making process (Part 6, Subpart 78: Community views in relation to decisions).

As managers working within the local government environment, public librarians would seem to have an obligation to seek the views of their current and potential customers when making decisions about the provision of public library services.

\subsection{Public library collection management}

Formal, written library policies are statements about decisions the library has made in relation to functions it performs or services it provides. In particular, a collection development policy sets out the framework for collection management decisions for the library's funding authority, its staff and its users. 
A number of environmental factors are contributing to the continuing importance of collection development policies in New Zealand public libraries. These factors are:

- The increasing costs of recreational and informational resources,

- libraries materials budgets that do not keep up with rising costs,

- an increased volume of publishing output,

- the prospect of competition from commercial information providers,

- pressures from the library's funding authority to demonstrate budgetary accountability,

- increased emphasis on user satisfaction as a determinant of the relevance of the public library's role.

Collection management issues continue to occupy a central role in $21^{\text {st }}$ century New Zealand public library management. The contemporary public library manager needs to engage with his/her community to ensure that effective and efficient collection management is achieved.

\subsection{Community consultation}

There are a variety of ways by which public libraries can involve their customers, and the wider community, in the policy making process. Techniques available to librarians for obtaining information about the community include: 
1. "Direct" methods: User satisfaction surveys and questionnaires, focus groups, "friends of the library", planning committees, user interviews, participation in community events and meetings, contact with local organizations and institutions (schools, businesses, community groups), monitoring the local media (community newspapers, club newsletters, local radio station), library comments and complaints procedures, staff feedback.

2. "Indirect" methods: Obtaining census information, using data collected by local agencies, use of research consultants, analysis of circulation statistics, analysis of requests, monitoring in-house use of materials, gate counts, in-house video monitoring.

The connection between community information gathering and policy development activities can be illustrated by the following diagram:

Figure 1: A cycle for collection development policies
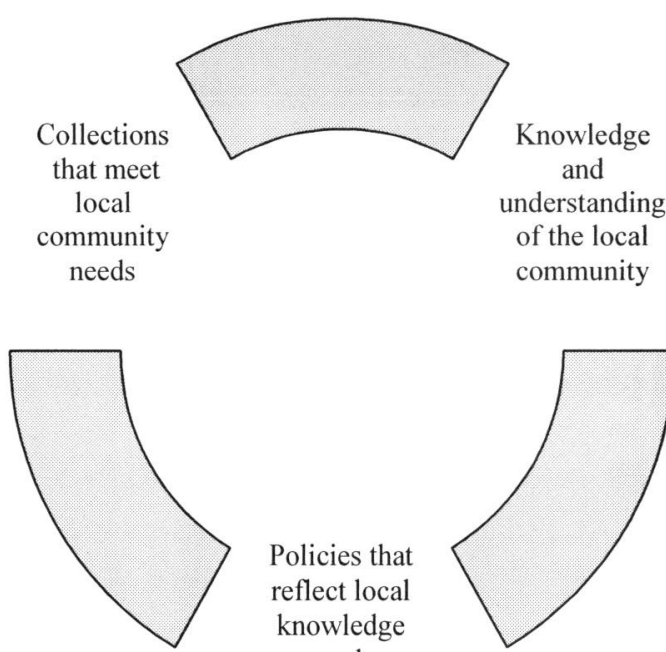

Policies that reflect local knowledge and

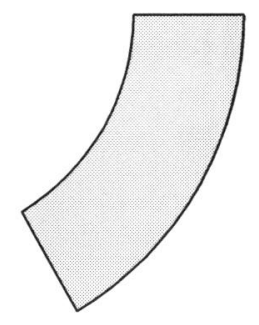

understanding 


\subsection{Purpose of research}

The purpose of this research will be: firstly, to investigate the methods used by a sample of New Zealand public library managers to obtain information about their customers' and communities' needs; and secondly, to investigate how this information is incorporated into their libraries' collection development policies.

The processes involved in community consultation, and in community analysis, are essential steps in ensuring that public libraries' collection development policies reflect customers' needs, and are continually responsive to them.

\section{Literature review}

\subsection{Introduction}

The literature review sets the framework for this research study of collection development policies in New Zealand public libraries.

The review begins with a definition of the key term used in this proposal. This is followed by a summary of the advantages to libraries in having written collection development policies.

The main content in this section is an outline of important themes in collection policy development, and in community consultation and analysis, arising from the 
international professional literature. Many of these themes are inter-related. The concepts presented are: the activities involved in policy formulation; the methods of community consultation; the techniques of community needs analysis; the processes of strategic planning; and the principles of marketing.

Throughout the review, links between the concepts are indicated, and the application of these concepts to the proposed practical study discussed.

\subsection{Definition of terms}

Clayton and Gorman $(2001,17)$ help to define the terms used in this study. They discuss the current usage of the term "collection development policy" and compare this with the more current "collection management policy".

A collection development policy is described as: “... a statement of general collection-building principles which delineates the purpose and content of a collection in terms relevant to both external and internal audiences". The policy is further described as being "... a contract between a library and its users" (19). The authors stress that a collection development policy should be a flexible, constantly evolving document.

By contrast, a collection management policy is described as: “... g global statement about a library's collections" (17). The authors conclude, however, that in current professional practice at least, the two terms are being used interchangeably. 
The term that will be used to describe the central phenomena of this study is "collection development policies". This term will encompass all of the policies a library may operate in the collection development and collection management areas. These policies may take the form of a single, formal written policy document, or they may consist of several informal and unwritten library practices and procedures.

\subsection{Functions of collection development policies}

Clayton and Gorman $(2001,20)$ and Gorman and Kennedy $(1992,4-5)$ refer to the work of Gardner in setting out the reasons for the value of written collection development policies in libraries.

The advantages of a formal, written collection development policy are that it:

1. forces staff to think through library goals and commit themselves to these, helps them to identify the long- and short-range need of users, and to establish priorities for allocating funds,

2. helps assure that the library will commit itself to serving all parts of the community, both present and future,

3. helps set standards for the selection and weeding of materials,

4. informs users, administrators and other libraries of collection scope, and facilitates co-ordination of collection development among institutions,

5. helps minimise personal bias by selectors, and to highlight imbalances in selection criteria, 
6. serves as an in-service training tool for new staff,

7. helps assure continuity, especially in collections of any size, providing a pattern and framework to ease transition from one librarian to the next,

8. provides a means of staff self-evaluation, or for evaluation by outsiders,

9. helps demonstrate that the library is running a business-like operation,

10. provides information to assist in budget allocations,

11. contributes to operational efficiency in terms of routine decisions, which helps junior staff, and finally,

12. serves as a tool of complaint-handling with regard to inclusions or exclusions.

During the course of data gathering for this research, information may be obtained about the range of roles that formal collection development policies are fulfilling in non-metropolitan New Zealand libraries.

\subsection{The New Zealand situation}

There is a scarcity of writing in the New Zealand professional literature about either collection development policies, or about the role of community consultation in policy formulation. However, the theory as to what public library managers should be doing in these areas is clearly stated.

The Standards for New Zealand Public Libraries (2002) specify the responsibilities of the public library manager in regard to collection development policy preparation, and strategic planning activities. 
Public library managers are required: "To prepare a collection development policy for the use of library staff and users" (Section D.2.2). Importantly, the policy "...needs to be assessed on a regular basis with changes in the community profiles, changing levels of use, demands for new services, developments in technology" (Section D.2.2).

A prior section in the Standards requires the library manager to undertake shortand long-term planning activities. One component of planning is: "An assessment of community needs..." (Section A.2.9). The following paragraph recommends that library managers "....conduct at regular intervals, comprehensive surveys and analyses to determine user and non-user needs, preferences and satisfaction levels" (Section A.2.10).

Compilers of the New Zealand Standards are likely to have adopted the concepts of strategic planning and community needs assessment from the overseas literature. One of the functions of this research will be to determine the extent to which theories developed offshore are being applied in New Zealand public library practice.

\subsection{Policy formulation}

At the heart of this research study is the intention to discover how, in practical terms, New Zealand public librarians engage in the process of formulating collection development policies. 
Cassell and Futas' (1991) manual provides just this type of practical advice, for managers of small and medium sized libraries in the United States. (The material in this manual could possibly be regarded as a little dated by those librarians, in comparison with Nelson's (2001) more current planning approach).

The authors emphasise the importance of involving the community in developing a collection plan, because doing so results in the library's policies clearly reflecting their customers' needs. The authors recommend the use of community consultation and information gathering techniques, and conclude that a collection development policy that has been based on community consultation is a powerful public relations and marketing tool for the public library.

Several of the research strands outlined in Section 5 of this proposal draw directly from Cassell and Futas. Moreover, the data gathered in response to the research questions may enable the researcher to compare policy formulation practices in a sample of medium sized New Zealand libraries with those of counterpart institutions in the United States.

Intner (2002) succinctly offers some further practical advice for librarians involved in collection policymaking. Her ideas will also be explored with the participants in this study. She stresses that written documentation is a powerful collection management tool, but she also cautions that policy and practice must work together in libraries. The author focuses librarians' attention on the cyclical nature of strategic collection planning - once the plan has been completed, the process must start again. 


\subsection{Community consultation}

New Zealand public library managers' use of community consultation principles is a key focus for this study, partly because of the importance of these principles in the current local government political environment.

Community consultation, as mandated by central government legislation, is perhaps not playing as important a role as it could in public library management in the United Kingdom.

Morris and Barron's research (1998) sought to discover which techniques had been used by librarians in the 183 library authorities in that country to consult with their user populations. The authors also surveyed respondents about the context for that consultation, and asked their opinions about the benefits and/or disadvantages of each method.

The authors reached the conclusion that U.K. librarians need to consider using multiple methods of ongoing consultation with their users.

The current research draws upon the framework provided by Morris and Barron. Exploratory discussions with a sample of New Zealand public managers may uncover the consultative techniques most frequently employed in this country. 


\subsection{Community needs analysis}

Most authors in this literature review have incorporated into their writing ideas derived from the theory of community needs analysis, or assessment, even though they may not have specifically labelled them as such.

Biblarz et al. provide a comprehensive outline of the components of this management technique. They define a user needs assessment as “... a process of using one or more techniques to collect and analyse data regarding library users or potential users. Specifically, the data collected will be directly or indirectly related to the needs, in the broadest sense, of users, or customers, for information in all formats" (viii).

A user needs assessment can be applied to diverse problem situations in collection management. One of the specific applications identified by these authors is to collect data to inform mission statements and policies.

The methods outlined in this manual for obtaining information about customers' needs, through either direct user input, or through secondary data gathering, are used as a basis for one of the key investigative strands of this study.

Biblarz et al. state that any user needs assessment project must start with a costbenefit analysis. Westbrook $(2000,26)$, on the other hand, feels that librarians should adopt a more "holistic" approach. By doing so, the library will reap benefits that go beyond the final report (or policy document). 
The idea that community consultation may result in "spin-off" benefits for the library, which may not be directly related to collection management issues, is a sub-theme which will be explored in this research.

\subsection{Strategic planning}

Another management tool available to public librarians is strategic planning. Nelson's manual (2001), published on behalf of the American Library Association, is the fourth version of a document setting out a recommended planning process for public libraries in the United States.

The formal approach to library planning described by Nelson, and the degree of citizen participation involved, possibly do not translate well to the political framework within which New Zealand public libraries operate.

However, the benefits of community involvement in public library activities, as identified by the American experience, are relevant to the current study.

Stephens (1998) has researched the impact of the Public Library Association's planning guidelines on collection development policies and practices in the United States. Her 1991 study found that many of the 255 libraries surveyed had used the planning process to create and revise their collection development policies and plans (18). Further, for many libraries, the development and revision of policies resulted in specific changes in collection development procedures and practices 
(19). The librarians surveyed acknowledged the importance of the community analysis step in the planning process.

Stephens' findings in this report, and in a more recent review into the extent of citizen participation in U.S. public libraries (2003), provide an underlying principle for this study: that there is inherent value in involving the community in public library planning activities.

\subsection{Marketing}

Marketing is the final managerial theory which contributes to the framework for this study. Baker and Wallace (2002), writing about collection development and promotion issues, advocate a societal-marketing orientation, which: "Requires that librarians identify the needs and wants of their customers and satisfy these, maintaining or enhancing the well-being of both patron and society..." (48).

Baker and Wallace differ from the previous authors is that they downplay the importance of a library's collection development policies, instead emphasising long range strategic and marketing plans. Nevertheless, the overall aim of their marketing philosophy, to create collections that will satisfy users, coincides with the central proposition of this study. 


\subsection{Conclusions}

This research study aims to investigate how community needs shape policies which in turn lead to responsive collection management practices in New Zealand public libraries.

Several, inter-connected themes from the international professional literature have been drawn upon to provide the theoretical basis for the study. These themes would seem to be relevant to current public library practice in New Zealand, but the extent to which they are being applied is unknown, since very little has been written about collection development policies, or the role of community consultation, in the New Zealand professional literature.

Important themes which have been covered by the international literature include: societal-marketing, strategic library planning, user needs assessment, and community consultation methods.

As will be explained in the following methodology section, this study will make use of an interview topic guide to explore whether "best-practice" concepts drawn from overseas experience can be identified in the non-metropolitan, New Zealand public library setting. This study might possibly reach the conclusion that the application of these theories is contributing to improved collection management practice in this country. 


\section{Study objectives}

- To investigate the methods of community consultation used by New Zealand public library managers.

- To research the use by public library managers of "indirect" methods of gathering information about their customers.

- To investigate how the results of community consultation and information gathering are reflected in the public libraries' collection development policies.

- To describe methods by which public library managers manage ongoing community consultation, as a means of ensuring that their library's collection development policies continue to reflect community and customer needs.

- To examine public library managers' attitudes towards the value of community consultation in contributing to effective public library collection management.

- To help identify "best practice" in policy formulation, in order to contribute to discussion on collection management issues amongst the New Zealand public library profession. 


\section{Research questions}

\subsection{Research problem}

As part of responsive collection management practices, what consultative processes are used by public libraries during the formulation and application of collection development policies?

\subsection{Principal research question}

How are customers' needs reflected in the formulation and application process of public library collection development policies?

\subsection{Research questions and sub-questions}

1. What types of community consultation techniques have been used by the library to obtain information about customers and the community?

- Why were these particular techniques chosen?

- How effective were these techniques in obtaining information about customer and community needs?

- What were the benefits and drawbacks for the library of the particular techniques employed? 
2. What "indirect" methods were used by the library to obtain information about customers and the community?

- How useful were these methods for obtaining information about customer and community needs?

- What were the benefits and drawbacks for the library of using this type of information?

3. Was the information gathered about customers and the community used in the formulation of a written collection development policy?

- If so, what mechanisms were used to incorporate the information gathered into the policy document?

- If not, was the information gathered used in unwritten collection development policies and procedures? If so, in what ways was the information used?

4. Was any follow-up done by the library to gauge the community's viewpoint about the value of the consultation process?

- If so, how was this follow-up done? 
- If so, what was the community's opinion of the value of the consultation?

5. From the library's perspective, did any benefits accrue out of the consultation process that were not directly related to the formulation of collection development policies?

- If so, what were those benefits?

6. Does the library have an ongoing commitment to monitor community needs, and to regularly review its collection development policies?

- If so, what type of ongoing consultation does the library intend to engage in?

- If so, how frequently, and in what ways, will the collection development policies be reviewed?

- If not, does the library intend to review its collection development policies in other ways? 


\section{Population/sample}

New Zealand public library managers are the group of professionals most likely to be able to provide answers to the questions underlying this research.

The sample to be used in the study will be drawn from medium-sized public libraries in the lower North Island region. This is a purposive sample, to the extent that it includes "...representatives from the population being studied who have a range of characteristics relevant to the research project" (Gorman and Clayton 1997, 127). The sample is not representative of libraries serving metropolitan areas in New Zealand.

The specific sites for the study will be:

\begin{tabular}{|l|l|r|}
\hline \multicolumn{1}{|c|}{ Library } & \multicolumn{1}{|c|}{ Council } & Population \\
\hline Feilding Public Library & Manawatu District Council & 28,600 \\
\hline Horowhenua Library Trust & Horowhenua District Council & 30,000 \\
\hline Palmerston North City Library & Palmerston North City Council & 72,033 \\
\hline Porirua City Library & Porirua City Council & 49,800 \\
\hline Wanganui District Library & Wanganui District Council & 43,269 \\
\hline
\end{tabular}

(Information about these local authorities can be found on the websites listed in Appendix A, 124.) 
All sites are located within two hours' drive of the researcher's home on the Kapiti Coast.

Participants in the study are likely to demonstrate a variety of personal and managerial styles.

Study participants will be individually invited to take part in the research.

Informed consent will be obtained by the researcher, who will undertake to ensure the confidentiality of the information provided by the participants, and the anonymity of the participants and their institutions in the final research report.

A pilot study will be conducted with the library manager of Hutt City Libraries. This site serves a metropolitan population of 100,000 . The pilot study should provide the researcher with an opportunity to refine the research topics, and possibly to gain the respondent's viewpoint about the study. The pilot study will also enable the researcher to practice interview techniques, to test the interview topics, and to check mastery of the recording equipment. 


\section{Methodology}

\subsection{Qualitative methodology}

This study will use a qualitative research methodology.

Cresswell (2003, 181-2) describes eight characteristics of this type of research:

Qualitative research:

- takes place in natural settings,

- uses multiple methods that are interactive and humanistic,

- is emergent, rather than pre-figured,

- is fundamentally interpretative.

The qualitative researcher:

- views social phenomena holistically,

- systematically reflects on who he or she is in the inquiry, and is sensitive to how his or her personal biography shapes the study,

- uses complex reasoning that is multi-faceted, iterative, and simultaneous,

- adopts and uses one or more strategies of inquiry as a guide for the procedures in the qualitative study.

A qualitative research approach aligns with the exploratory nature of this research study. 
The researcher is seeking to understand the nature of the role played by collection development policies in public library settings in New Zealand. The researcher is also seeking to gain insights into the reasons why public library managers may, or may not, choose to gather information (either directly or indirectly) about their community and their customers when devising and implementing these policies.

The research questions this study is posing do not lend themselves to quantifiable information gathering techniques. However, if time permitted, a more extensive study could be undertaken, using a mixed methods research approach. In this case, the second phase of the research would involve using the findings of the current study to develop a survey questionnaire. This questionnaire would be administered to managers of public libraries throughout New Zealand serving similar-sized populations as the sample group. Use of a two-step methodology would enable the researcher to verify the applicability of the current study's findings to the entire population.

\subsection{Data collection}

Data for the study will be collected by means of the researcher conducting oneon-one interviews with the population sample. A group interview is not regarded as being practical - it would be unrealistic of the researcher to expect library managers to travel to a central location to participate in such a discussion. 
The advantages of the interview method are outlined by Gorman and Clayton (1997, 124-5). These advantages are relevant in both contextual and practical terms to the proposed study. The advantages are:

- they permit an immediate response to questions,

- they allow both researcher and participant to clarify the meaning of questions and answers,

- they enable exploration of why individuals and organizations behave the way they do,

- they are friendly, offering personal contact,

- they result in the collection of a large amount of data in a short space of time.

Gorman and Clayton also outline the disadvantages of interviews, which are:

- they require a large amount of researcher time,

- it is difficult to sort the important data from the unimportant,

- the participants are denied anonymity,

- there is significant potential for bias.

Consideration has been given to these disadvantages: limiting the study to five participants may render the time requirement more manageable; the researcher will discover the difficulties raised by the second point during the course of the study; the question of anonymity may be less important in this study, which is 
based on the participants' professional, rather than personal, lives; the potential for bias in this study is formally acknowledged later in this section.

\subsection{Specific procedures}

Interviews will take place either at the study participants' place of work, or at a venue of their choice.

The interviews will follow a semi-structured format, using the study's research questions as a topic guide. The researcher will expect to depart from the guide in order to explore issues in more depth which each participant, as the situation arises. Participants will receive a copy of the topic guide in advance of the interviews taking place.

Each interview will be of approximately one hour's duration. The researcher will tape record each interview and the tape recordings will be transcribed by another person.

\subsection{Limitations of study}

1. Instrument bias. Acknowledgement is made that the researcher may bring personal bias to the study, based on her experience in the public library profession. However, the potential for bias will be minimized in the interview situation through the researcher allowing the participants to take 
the lead in determining the course of the discussions. The pilot study should also serve to alert the researcher to possible areas of personal bias.

2. Participant bias. The information obtained during the course of the interviews will be a reflection of the participants' viewpoint only, and will not necessarily be an accurate representation of the situation as a whole. To overcome this, the researcher will, where appropriate, pose questions which may prompt the participants to verify the statements they have made. It is acknowledged that interpersonal dynamics between interviewer and participant may affect the quality of the interview.

3. Sample size. The population sample chosen for this study is purposely small - extended, in-depth interviews will enable the researcher to gather rich data from each participant. However, it is accepted that the findings will not be able to be generalized to New Zealand public library settings as a whole.

\subsection{Validity}

Methods that will be employed to increase the internal validity of the study's findings are as follows:

1. Member checking. Written reports of each interview will be returned to the participants, allowing them the opportunity to correct transcription errors. 
2. Peer review. The researcher's academic supervisor will review each stage of the research study.

3. Triangulation. This will be achieved to some extent by the collection of data from two additional sources:

- The collection development policy documents from each participant's library (where available) will provide an additional data source for the study. Content analysis of these documents will determine whether they demonstrate evidence of community consultation, or data gathering, processes.

- Throughout the period when interviews are being held, the researcher will keep a parallel set of reflective notes containing external observations about the interview situation, and internal impressions and thoughts about how the interview went and the data that was presented.

Both of these data sources will be analysed according to the methodology outlined in the following section. 


\section{Methods of data analysis}

Methods for the analysis of data gathered during a qualitative study are outlined by Cresswell (2003, 190-195), Rice-Lively (1997, 198-212), and Finch (1990, 139-146).

All authors emphasize the complexity and time-consuming nature of qualitative data analysis. Leedy and Ormrod $(2002,161)$ refer to Cresswell's "data analysis spiral" which illustrates the non-linear nature of the process.

The methods that will be used in this particular study are described in the following paragraphs.

The textual data that will be used for analysis during this study will comprise:

- Transcripts of the interviews held with each participant,

- collection development policy documents (if available),

- reflective notes made by the researcher during the data gathering process.

The guiding principle for the researcher during the analysis phase will be to find answers to the primary research question, ie. to discover how customers' needs are reflected in public library collection development policies.

A conceptual framework for the analysis will be provided by the topics covered by the study's research questions, as outlined in section 5 . All of the concepts 
developed during the analysis will be based upon the contents of the data (Finch, 130-1).

During the preliminary data analysis phase, the researcher will read through the data several times, to gain familiarity with its contents. The researcher will start to think about themes and relationships that might be contained in the data.

The researcher will compile a list of the issues that are emerging out of the data. These issues will be grouped into broad themes or categories. The terminology used to describe each category will be derived from words used in the data sources.

The researcher will develop a simple coding manual which will use alphabetical symbols to represent each identified theme.

During the phase of more detailed data analysis, the researcher will systematically work through each unit of data. Data units are the "...smallest pieces of information that may stand alone as independent thoughts ..." (Rice-Lively, 204). One or more codes will be assigned to each unit. Coloured markers may also be used on the text, as an additional method of highlighting the coding categories.

During the coding, particularly pertinent quotations from the interview transcripts, or other data, will be identified. 
When all data has been coded in this way, the researcher will reconfigure the material. All material on related themes will be grouped together. Finch (143) recommends the use of two-way charts on sheets of A3 paper for this purpose. Another method would be to cut up each page of text, making copies of data that has been assigned more than one code, and to group these pieces of text.

The researcher will reflect on the data, to arrive at a synthesis of its meaning. Finch (140) describes this process as involving questioning the data, looking for relationships between variables, noting the researcher's own reactions to the findings, questioning further and developing ideas, then going back to the data for verification.

The researcher may prepare a diagram, or other visual presentation, as a means of presenting a summary of the data.

Finally, the findings of the study will be compiled into a narrative in a research report. 


\section{Carrying out the field research}

\subsection{Participant contact}

Preliminary telephone contact was made with the pilot study participant, then with all the research study participants. As a result of these calls, dates and times were arranged for interview appointments. All participants contacted were willing to take part in the research. However, in the case of the two largest institutions in the sample (one of these being the pilot study), the researcher was referred to a specialist, second-tier manager within the library.

Upon receiving verbal acceptance, the researcher posted to each participant a copy of the information letter setting out the background to the study (see Appendix B, 125 ) and a copy of the consent form (see Appendix C, 126). The signed consent forms were collected from the participants at the conclusion of the interviews.

\subsection{Interview schedule}

All interviews were held over a ten-day period, from the $9^{\text {th }}$ to the $22^{\text {nd }}$ of December 2003 (see interview schedule, Appendix D, 127).

The pilot study took place three days before the interview schedule proper commenced. The main value to the researcher of the pilot study was in prompting a reconsideration of the planned interview approach (see discussion following). 
Interviews were held at each participant's workplace, in a private office. Prior to beginning each interview, the researcher sought verbal consent from each participant to tape-record the conversation.

All but one of the interviews was of 30 minutes' duration - the longest session lasted for 45 minutes.

\subsection{Structure of the interviews}

The researcher's original intention had been to conduct semi-structured interviews, using the study's research questions as a topic guide. However, upon completing the pilot interview, the researcher judged that the phrasing and ordering of the research questions was possibly too formal, and that a more conversational format might better suit the reality of professional practice.

Accordingly, during the research study interviews, the researcher kept the research topics in mind, but did not follow a set order of questioning. Participants were encouraged to provide as much information as they could about topics related to their institution's work practices, but weren't pressed to provide responses to topics which seemed to hold less interest for them. Where possible, the interviewer attempted to use statements arising out of the conversation as a way of making a transition to the next topic.

One of the benefits of the conversationally-structured interviews was that the researcher was able, at each successive interview, to raise topics that had been 
discussed by previous participants. The researcher acknowledges that not all research questions were necessarily posed to each participant - this is probably one of the drawbacks to the informal interview technique.

\subsection{Transcription and verification}

All interview tapes (except one) were transcribed by a professional secretarial service. All transcriptions were completed within 24 hours of the interviews being held. Each transcript was checked against the recording by the researcher and transcription errors corrected. No corrections were made to either the vocabulary or grammar used by interviewer and participant.

At one site, due to either technical failure or operator error, the tape-recording of the interview did not succeed. In this case, the researcher, on the day of the interview, made notes from memory about the main points discussed by the participant. These notes were emailed to the participant, seeking comment as to the report's factual accuracy; however, a response was not received.

Once each transcript had been completed, a copy was emailed to each participant. In most cases, this occurred within 48 hours of the interview taking place, Participants were asked to comment only on the accuracy of the transcription. As it eventuated, no such comments were received. 


\subsection{Collection development policies}

The researcher obtained a copy of the institution's collection development policy document from the pilot study site, and from three of the research study sites, one of which was in draft format. Of the two remaining sites, one had a collection development policy document in preparation, and the other did not provide a copy of their policy.

\subsection{Reflective notes}

On the day that each interview was held, the researcher wrote a brief set of reflective notes, containing personal observations and insights about how the interview had proceeded.

\subsection{Advantages and disadvantages of the interview method}

The researcher's personal experience of conducting research interviews accords in most respects with the points made by Clayton and Gorman in section 7.2 of this report.

The researcher found that, because of the immediacy of the interview situation, both participant and interviewer were able to seek clarification about the questions that were asked, and the responses that were given. The exploratory nature of the interviews meant that the researcher was able to develop an understanding about the way in which each library was operating. The researcher enjoyed the 
opportunity presented by the study to make personal contact with working professionals.

The researcher found conducting the interviews to be fairly stressful and, judging from the informal comment of one participant, this was probably true for the interviewees as well. The researcher found the interview situation both physically and mentally draining, which was probably one of its drawbacks. Another drawback is that the inexperienced interviewer is likely to miss potential opportunities for engaging participants in in-depth reflection.

In order to reduce the time-commitment of the data gathering phase of the project, the researcher made the decision to engage a professional secretarial service to transcribe the interview tapes.

The researcher found that a large quantity of data was obtained during interviews of relatively short duration. The researcher is aware, however, that not all of this material may relate directly to the research topic.

It is difficult for the researcher to assess the degree of bias that may be present in the data gathered during the interviews. Each interview was unique, to the extent that each participant's responses demonstrated their individual personality, and their differing professional experience and managerial outlook. Also, each participant's responses were no doubt filtered to a certain extent by their reaction to the presence and personality of the interviewer. 


\section{Carrying out the data analysis}

\subsection{Data sources}

The researcher assembled the data which would be used in the analysis, which comprised:

- 4 interview transcripts

- 1. set.of interview, notes

- $\quad$ collection development policies (1 in draft format)

- $\quad$ handwritten reflective notes.

The researcher gained familiarity with the material contained in the transcripts by reading through each one two or three times, in conjunction with listening to the recordings of the interviews.

\subsection{Development of coding themes}

The researcher developed a list of coding themes (see Appendix E, 129). These themes were based upon the research questions which had served as the interview guide.

The themes consisted of two main strands: A: an examination of the methods used by the study participants to obtain information about community and customer needs; and, B: an examination of the nature of the formal and informal collection development policies being applied at the study participants' institutions. Theme 
"A" was further subdivided into two categories: (i) an investigation of the "direct" or consultative methods of obtaining information, and (ii) an examination of the "indirect" or data-analysis methods of gathering information.

The techniques which make up these methods were listed in the section 2.3 of the introduction to this report, and have been drawn from the framework offered by the theory of community needs analysis, discussed in section 3.6 of the literature review. An additional theme of "Observations" was added to the list of direct consultative methods, because the study participants frequently referred to their own professional experience and judgment as being a valid source of information about their community and their customers.

The primary focus of this research study has been to investigate public librarians' use of community consultation methods. However, equal coverage has been given to "indirect" data-gathering methods because of their widespread use by the study participants, and because these methods played an equally important role in the formulation of the participants' formal and informal collection development policies. Comparing and contrasting the two types of methods assists with answering the research questions.

After developing the main thematic strands, the researcher devised two separate sets of sub-themes. These sub-themes were also based upon the research questions, but included additional concepts that were based upon topics raised by the participants during the interviews. For example, most participants discussed with the researcher the methods by which materials selection activities were 
managed within their institution. Accordingly, the researcher added a sub-theme of "Selection" to the collection development policies theme, to encompass this material.

It should be noted that not all of the topics covered by the research questions are included in the coding list. In particular, Question 4 (by which the researcher had intended to discover whether any feedback had been sought from members of the community about the value of the libraries' consultative processes) does not have a corresponding coding theme. The reason for the omission is that this line of questioning was not pursued with the interview participants. The researcher realized that none of the participants was undertaking consultation in a systematic enough way to have incorporated feedback mechanisms into the process.

\subsection{Coding of data}

Once the coding list was prepared, the researcher systematically worked through each of the data sources, assigning codes to each "unit of independent thought". For example, the statement by one participant: “...we've got 'suggestions for purchase' cards at all the desks, so we're encouraging community input into what we're purchasing in that way..." was assigned the coding label "Cop/Rol". This indicated that the unit of data related to the theme of library comments and complaints procedures, and that it specifically illustrated the way in which a "direct" information-gathering technique is contributing to that library's collection development policies. 
Sometimes, more that one coding theme could be applied to each coding unit; however, the researcher found that throughout the transcripts participants often repeated points by stating them in a slightly different way. This duplication of material meant that the researcher was often able to apply a second coding theme to the alternative statement.

During the coding process, the descriptions of the labels (see Appendix E) were frequently revised, and some initial sub-theme ideas were deleted or combined. During coding of the formal collection development policy documents, additional sub-themes were added to the "B" thematic strand.

\subsection{Grouping of data}

When all of the data units had been assigned a coding label, the researcher prepared separate sheets of A4 paper for each thematic coding label and manually copied each coded data unit onto the sheets.

The researcher found this stage of the analysis to be very time-consuming, because of the need to think constantly about the meanings of the data units, and to identify which aspects of the research questions they might most usefully illustrate. 


\subsection{Preparation of two-way charts}

Using unlined sheets of A3 paper, the researcher then prepared four, two-way charts (Appendix F, 131). The first two charts were used for a detailed interpretation of the data, while the second two charts attempted a more in-depth synthesis of the material. (A description of the purpose of each chart follows below.)

The researcher reviewed the data that had been grouped onto the A4 sheets, and transferred summaries of the main points onto the A3 charts. References to direct quotations, and comments by the researcher were also added to the sheets.

\section{Chart 1: Analysis of information-gathering methods}

This chart was used to summarize the main points arising out of the data relating to the methods used by library managers to gather information about customers and the community, which could then be used in formal and informal collection development policies.

\section{Chart 2: Analysis of collection development policies}

This chart was used to summarize the data that illustrated the similarities and differences between the informal and formal collection development policies that were being formulated and applied by the library managers.

Chart 3: Comparison of information-gathering methods 
This chart was developed to highlight the similarities and differences between the "direct" and "indirect" information-gathering methods, according to the experiences of the study participants. This chart further developed the data from Chart 1.

Chart 4: Summary of the relationships between information-gathering methods and collection development policies

The researcher felt that this chart worked the least successfully. The intention was to address the study's principal research question: "How are customers' needs reflected in the formulation and application processes of public library collection development policies?" However, the researcher found that an attempt to further refine the data from Chart 2 resulted only in very broad statements. The researcher concluded that the reason for this result was that the study participants did not perhaps clarify the nature of the relationships between the two concepts within their institutions.

Upon completion of these charts, the researcher felt that the data obtained in the field had been gathered together sufficiently to function has a writing guide for the drafting of the following section of this report.

The qualitative data analysis methodology used in this study is a simplified version of that described in the literature. This is probably due to the small sample used in the study - a larger sample would no doubt have involved the researcher in a more complex questioning of the data. 


\section{Analysis and interpretation of findings}

The structure of this section of the report will follow the order by which topics were addressed during the analysis of the research data. The data analysis was based upon the ordering of the research questions in Section 5 of this report.

Throughout the following narrative, direct quotations from the transcripts of the interviews with the study's participants will be used to illustrate the points being made. Direct quotations will be presented in italic type, in a format that preserves the anonymity of the participants.

The analysis begins with a discussion of the use by public library mangers of community consultative techniques, followed by a discussion of the managers' use of data-analysis techniques.

Table 1 presents a summary of the research findings relating to the "direct" and "indirect" methods of obtaining information about community and customer needs and wants.

The next section of the analysis is an examination of the ways in which formal and informal collection development policies are being formulated and applied at the study participants' institutions.

To conclude this section, Table 2 links the two main themes of the analysis: the techniques that are used to gather information about community and customer 
needs, and the role that this information plays in collection development policy formulation and application.

\subsection{Methods of community consultation}

This section will describe the variety of community consultative techniques used by the study's participants. Throughout this study, consultative techniques are defined as those which involve librarians in direct interaction with customers and the community, in order to discover their needs and wants.

The techniques which will be examined are: user surveys, focus groups, formal committees, liaison with schools, liaison with tertiary education providers, liaison with community groups, liaison with Maori, staff feedback, comments and complaints procedures, and professional observations.

Each of these techniques will be discussed in relation to the following questions:

- What purpose is the technique used for?

- What are its advantages or benefits?

- What are its disadvantages or drawbacks?

- How frequently is the technique used, and how is it carried out?

- How is the information gathered by the technique used in the formulation and application of collection development policies? 


\subsubsection{User surveys}

Study participants' understanding of this method was of written survey questionnaires, handed out to customers visiting the library. Most participants had made use of this consultation technique, although not necessarily for collectionrelated purposes.

Participants cited two reasons, in particular, for carrying out surveys: internal - to enable staff to find out what customers think about the library; and, external - as a means of ensuring ongoing support from the institution's funding provider.

“...we have run informal surveys and we've asked people what they like and what they don't like about the library."

"Politically... it can be very strong... because it does confirm that you're doing the right thing".

The main advantage of surveys to the participants is that they provide valuable feedback:

“...you get really good backups for what you're doing..."

Surveys can also give customers the opportunity to comment about aspects of the library service, and to put forward suggestions for things they would like the library to do. Surveys also help the library staff with planning for future 
collections: for example, one institution included a question in their survey about whether respondents had purchased a DVD player, or were thinking of purchasing one.

The main disadvantage of user surveys for the participants, particularly for those who don't carry them out regularly, was their cost. By cost, participants meant staff time, and also the cost of outside professional advice and assistance. Some participants expressed doubt that they would be granting funding from their parent institution for the purpose of carrying out a survey.

Typical comments were:

"...we can't really afford to do a serious survey..."

“...we can't do surveys...we just don't have the time..."

Other disadvantages about surveys raised by participants were: that it is extremely difficult to survey non-users; that it is difficult to ensure statistical validity; that the percentage of surveys returned is often low; that the public sometimes have difficulty in interpreting the meaning of survey questions; and, that members of the public often don't like to be critical about library services.

Only one participant's institution regularly carried out surveys: 
"I've been here ten years, and we would have done at least four in that time... we're due to do another one..."

Another participant commented:

"Collection-based ones are rarely held..."

Despite their significant drawbacks, the researcher concludes that user surveys which question respondents about library collections can play a valuable role in collection management, even if this information is used to support informal collection development decisions only. Surveys that are carried out regularly help to identify trends about what customers are wanting from the library.

Ideally, the role of user surveys in library collection planning is stated in the institution's formal collection development policy, as is the case for one of the study participants:

"The ...library carries out a bi-annual user survey and results from this also feed into buying policies". 


\subsubsection{Focus groups}

Focus groups are another consultative technique that had been used by most of the study participants although, as was the case with user surveys, this was not necessarily for collection management purposes.

In a similar way to user surveys, focus groups were used to find out:

“...primarily, what people want from the library...not necessarily the library collections..."

Focus groups had been held with both current library customers, and with people who were not currently using the library.

All participants agreed that the focus group technique has numerous advantages. Firstly, the technique allows groups of people to be selected who are representative of the diversity of the library community. Also, non-users can be targeted by this method:

“...we had one group interested in children's services... and one group of general people, as diverse as we could think of..."

"...we had a group of people who I know were not borrowers..." 
Further, people who are known to have a genuine interest in library services can be chosen to participate in focus groups, and these groups may not necessarily be formally structured:

“... at a couple of branches we ran groups of regular users, just talking to them..."

Although participants acknowledged that focus groups can be successful, they were also very aware of the drawbacks of the technique. These drawbacks included difficulties in organizing representative groups of people:

"...the concern I've got...finding the right groups of people to do the consultation with..."

Participants also felt that the technique requires an outside facilitator:

"... I think you need somebody very skilled to run it..."

The difficulty of encouraging people who are not library users to participate in focus groups was illustrated by one of the participants. This library manager had the experience of people who had been invited to a focus group simply not turning up on the night, despite the incentive of supper being provided. 
Some participants felt that focus groups may be an ineffective technique because they don't measure percentages, and because the information gathered isn't valuable enough to warrant the effort involved:

“...we didn't feel that we got sufficient breadth of data to get a good picture..."

Also, many participants expressed unease about the possibility of focus groups being captured by the most vocal sectors in the community:

"I'm worried about the risk of skewing the collection in one direction because there's a pressure group and they're loud enough to skew it..."

Focus groups were not being regularly used as a community consultation technique by any of the study participants, although some felt that, on reflection, it was a technique they could make greater use of:

“...it would be good to establish a more formal structure of regular review..."

“... [it's] something we're going to want to get into, at least in the next 18 months..."

One participant, however, did not see any advantage in regular use of the method: 
“...we don't continue to do it...I'm not sure that you would get significant changes by doing it every year..."

Study participants did not elaborate upon the link between the conducting of focus groups, and the formulation and application of their library's collection development policies. However, the researcher feels that if focus groups were to become a regular feature of a library's community consultation programme, their potential to gather information of benefit to collection development activities could be more fully realized.

\subsubsection{Formal committees}

Public library planning committees, as described in the United States literature, are not a feature of public library management in this country.

However, two types of committee that were mentioned by participants in this study are library trustees, and "friends of the library".

For one participant, the advantage of working with library trustees is that they are a group of people who are well-informed and interested in library matters.

Another participant was dubious about the value of committees:

“...it's a bit like friends of the library...it's good to have but you don't want them taking over the library..." 
The role of the library trustees in the formulation of a written collection development policy was described by the participant mentioned formerly:

“...one of my trustees is a librarian... She believes in written policies...so we probably did it more thoroughly as a result of her..."

Those participants who had experience of working with "friends of the library" committees agreed that such groups fulfill a role as representatives of the wider community. If well managed, they can be an additional source of information about the needs and wants of the community.

11.1.4 Liaison with community institutions - schools

For the study, "community institutions" is defined as institutions within the community, other than the public library, which are providers of information to that community. The data gathered by this research focuses specifically on two types of institutions: schools, and tertiary education providers.

All of the study participants' institutions liaised with the schools in their community, although some felt their links were stronger than others:

"...the links we have with schools, and with educational institutions, would be pretty...good."

"...we're trying to improve it... [ie. liaison with schools]" 
Participants liaised with schools for the purpose of supporting the school curriculum, and in order to work in conjunction with schools to promote a lifelong love of reading amongst children.

The main advantage of schools' liaison for the participants is that it creates a personal link between the public library and the school:

"...they know the people they're dealing with..."

The main disadvantage to schools liaison seemed to be that it is reliant on mutual co-operation to work successfully:

“...it's reliant on whether you've got good teaching staff who're prepared to communicate..."

For most participants, consultation with schools occurs continuously:

“...definitely lots of school visits... and the mobile goes out to lower decile schools..."

“...our children's librarian would visit the schools probably more than any small town children's librarian I know of..."

The role that consultation with schools plays in their libraries' collection development policies was clearly stated by the study participants. In every 
institution, purchasing of materials for the children's section of the library was undertaken by the children's librarian. The frequent contact that these librarians have with the schools informs the collection development decisions they make.

The role of supporting "educational" goals was also specified in the participants" formal collection development policies:

"Our policy is to provide a high quality collection of books which can be read for interest or to supplement material provided by the schools".

The researcher concludes that, for most study participants, the efforts that are being made to liaise with schools are an example of successful community consultation practice.

11.1.5 Liaison with community institutions - tertiary education providers

When discussing their relationships with local tertiary education providers, the participants referred to formal education providers, such as universities and polytechnics, as well as to providers of less formal courses, such as community learning centres.

Participants liaised with tertiary education institutions for differing purposes. Some participants did so in order to be able to support the programmes being taught: 
"People want course-related material and so we do buy it..."

"There's quite a number of private training providers in this district...we do have good links with all of those, and try and work together, certainly to establish what the needs of people doing private training are..."

Other participants supported the needs of tertiary students in the community in a more general way:

"...we certainly see them as part of the lifelong learning process that is definitely one of our roles to supply the needs of..."

However, one of the participants did not see it as being their institution's role to support tertiary education:

“...we definitely feel that we're set up for different purposes - we are not an education institution...we're not in the same business as they are..."

The main advantage of participants' liaison with tertiary institutions seemed to lie in the fact that it enabled each institution to clearly define its role with regard to the other. This definition of roles gave the participants a basis for developing their collection policies. For example, on the subject of the provision of library resources in electronic format, one participant commented: 
"...we're looking at electronic resources at the moment... and we're talking to the polytech and the university... about what they do and about what we do..."

The main drawback to liaison with tertiary education providers is that, as with schools, it requires goodwill on both sides to operate effectively. One participant remarked:

"...we don't have huge links with the polytech..."

For those institutions with established links, the consultation occurs on a regular basis, although perhaps not as frequently as with schools' liaison.

Most participants could quite clearly articulate the way in which consultation with tertiary education providers influences their collection development policies. One formal policy statement reads thus:

"We acknowledge services offered by other libraries... and where they are able to adequately meet demands, our service is appropriately modified or scaled down”. 


\subsubsection{Liaison with community groups}

When discussing this topic, participants described the consultation they engaged in with special-interest groups in the community, with different ethnic groups, and also with agencies supporting government programmes.

Consultation occurred to fulfill a variety of library collection development purposes. Several participants had liaised with ethnic groups in the community in order to establish collections of non-English language materials in the library:

"We've got quite a large Chinese and Japanese population...so we're starting a small collection of books in Asian languages".

Another participant had taken the opportunity to address the local branch of "Federated Farmers" with the aim of increasing that group's understanding of the role that the library played in the community.

Another institution had developed a relationship with special-interest groups in order to advance mutual goals:

"Co-operation and assistance to the historical societies in the district, to make their collections better known and more accessible, is an important factor in ensuring local history is preserved". 
In one community, the library manager is working with the local office of the Education Ministry, with groups of parents and care-givers, and with a research team from the university on a project to address the problem of poor literacy amongst children from lower socio-economic groups in the community.

Interaction with groups in the participants' communities often occurred on quite an informal basis:

“... whatever little network you're talking about in town...there is a library staff member not very far away from it..."

The advantages to participants of consulting with a wide variety of community groups are that it helps to build goodwill towards the library in the community, and that it can also provide valuable feedback for the library's collection development activities.

One disadvantage in establishing relationships with community groups is that sometimes the library cannot meet that group's expectations of it. One participant, speaking about the local business association, remarked:

“...we could say 'we're going to offer a service to business', but the materials budget simply won't stretch to that..."

For most participants, consultation with a wide variety of community groups took place on a regular basis: 
“...we've got strong alliances... with ESOL tutors. We've also got links with the jazz club and with people who're involved in radio stations...People with an interest in health..."

All of the consultation that participants were doing with community groups yielded information that was of direct relevance to the libraries' formal and informal collection development policies. The desirability of consultation was formally stated in one policy document:

“...selectors are encouraged...to liaise with relevant interest groups in the community".

\subsubsection{Liaison with Maori}

All participants considered consultation with Maori to be an important part of the library's role in the community. This is probably partly because local government in New Zealand has a formal obligation to involve Maori in decision-making.

Consultation with Maori was used mainly for the purpose of developing collections of Maori-interest materials, although one participant also acknowledged that meeting the general information needs of Maori is also a responsibility for the library.

Most participants had facilitated bicultural liaison in their institutions through the establishment of a dedicated staff position: 
“...we've got a Maori and Pacific librarian whose specific role is to liaise with the Maori and Polynesian communities..."

In addition, other participants felt that it was important that it was important to ensure there was a good proportion of Maori on the library staff:

"I've got ...senior Maori staff who belong to both the local iwi... have good links with their own hapu within their iwi... have credibility in their culture..."

Yet another participant made use of their parent institution's bicultural liaison framework:

“...the council has a marae consultative committee and they're regularly asked what they feel about the library..."

The advantages for study participants of undertaking Maori liaison are: it enables the library to better meet Maori information needs; and, it creates goodwill for the library amongst the Maori community.

For those participants with formal collection development policies, a commitment to meeting Maori customer needs is usually clearly stated: 
"Collections recording the collective memory and heritage of local Maori are a critical factor in service to the Maori residents of our district".

\subsubsection{Staff feedback}

All participants made extensive use of staff feedback mechanisms as a way of gathering information about library customer needs.

Feedback received from staff directly informed the libraries' materials purchasing and collection building decisions. It was also regarded by participants as an important method for fostering goodwill amongst the community.

The advantages of staff feedback as a consultation technique are that it occurs as a matter of course in everyday library activity, and that it operates informally:

"...being a small community, the staff are talking to the public all the time..."

"...everybody who works with collection management works on the desk...getting feedback about collections, hearing enquiries, generating informal feedback..."

This type of informal consultation is also used as a means of identifying the needs of groups who might otherwise be difficult to reach, such as teenagers: 
“...our summer reading programme...we've got a youth component, and that's a really good way to get their input and feedback..."

Some participants were also able to use the feedback they received from their branch librarians as a way of obtaining information about the types of materials that would best meet the needs of the smaller communities.

One drawback to the staff feedback technique is that it can be difficult to ensure that processes are in place to formally record staff's daily interactions with customers, and to then ensure that these are in turn incorporated into collection development practices. Participants achieved this through informal and formal staff meetings, and, in the larger institutions, through formal monthly reports by staff supervisors.

The importance of staff feedback in determining the direction of collection development was emphasized by all participants, and formed part of both formal and informal policies:

“...for me to buy in isolation would be foolish, because I don't see the public as much as my staff do..."

“All staff work regularly with the public and the library's collections, answer requests for information, and receive comments from users. In this way, deficiencies in the collection quickly come to light and changes in demand can be met..." 
This consultation method comprises both formal and informal comments and complaints procedures. The comments and complaints may be expressed either verbally or in writing, but are handled more formally than is the case with the dayto-day interactions that occur between library staff and customers.

In the smaller institutions which participated in this study, comments and complaints might be presented in a relatively informal way:

“...if I buy the wrong stuff, people are going to complain... and I'm going to find out about that pretty quickly..."

The larger institutions sought comments about library collections through the use of suggestion boxes, or an interactive website:

“...we've got ... a feedback box in the children's area, and we've got feedback forms on the website...there are ways that people can feed... we do get letters and notes..."

One disadvantage of comments and complaints procedures, raised by several participants, is that the most articulate customers are likely to make their views known, whereas other customers don't speak up: 
“...we do have a group of customers, who are generally white, middle class to high income, who are fairly vocal about what they want and when they want it, but they are only about $30 \%$ of the population, and the other $70 \%$ aren't making a lot of noise..."

As is the case with staff feedback procedures, the information that is received through the libraries' comments and complaints mechanisms can have a direct influence on collection development policies, as these two statements from formal policy documents show:

"Regular fiction readers are well informed, and often ask for new titles before they reach the shops. Because of this, the library tries to buy all titles by established fiction authors..."

"Selectors are encouraged to make use of borrowers' expertise and suggestions for purchase..."

\subsubsection{Professional observations}

The researcher was interested to discover the extent to which the study participants relied upon their own professional observations and judgments as a source of information about their communities and their customers. The researcher feels that this occurrence is probably due to the fact that most participants are long-serving library managers, with up to twenty years' experience in their current positions. 
Observations by library managers about their customers are used to provide a backdrop for collection-building decisions:

“... big use by the elderly, big use by students, average use by families, very limited use by middle class or middle aged people in the workforce..."

Professional judgment is also used to explain the behaviour patterns of groups of people in the community:

"...there are two main groups of people in society at the moment...the time rich and the time poor..."

"Teenagers are historically light users of libraries..."

The advantage of observation as a direct information-gathering technique is that the judgment of experienced professionals is likely to be highly valid. Such judgments can also provide valuable insights about sectors of the community that it would otherwise be difficult to obtain information about, for example, groups of people who don't use the library:

“...lots of the non-users are people who know perfectly well that the library is here, but don't need it regularly..." 
“...there's an overriding viewpoint that libraries are a good idea, and people think they should have them, but apart from until they actually want something, there's not a lot of interest in using it..."

The major disadvantage to reliance upon professional judgment, in the researcher's opinion, is that it may be used as the sole justification for current practices and procedures. Professional judgment probably always needs to be evaluated against information gathered through community consultation and data analysis techniques.

One study participant gave an example of how professional judgment is used to support informal collection development policy decisions. This participant had decided to expand the library's "bestseller" collection, because:

“...our observation would be that borrowers expect immediate gratification..."

One of the participant's formal collection development policy documents makes a very general statement about collection-building principles, which is based on the "general knowledge" of every public library professional:

"Library users have different attitudes, tastes and beliefs. This diversity should be reflected in the library's collections wherever possible..." 


\subsection{Methods of data analysis}

This section will describe the methods of data analysis used by the study participants to obtain information about community and customer needs and wants. These methods are described as "indirect" because the informationgathering doesn't involve direct contact with either members of the community, or with library customers.

The techniques to be discussed in this section are: use of census data; use of data gathered by local councils; use of surveys conducted by outside organizations; use of research consultants; analysis of circulation data; analysis of borrower activity data; analysis of gate-counts; analysis of in-house materials use; analysis of requested materials.

Each technique will be reviewed according to the sub-themes applied in the discussion of community consultation techniques, i.e.

- Purpose

- Advantages/benefits

- Disadvantages/drawbacks

- Frequency and methodology

- Role in collection development policy formulation and application. 

Census data

All of the study participants regarded the census figures for their district as being an important tool for library planning. The census provides demographic data about the community: age groups, income bands, ethnic groups, employment rates, schools etc.

One participant described the role of census data as being:

“... just sort of background... to focus our mind very clearly on what this structure's like... to be aware that each of our suburbs is very, very unique..."

The advantages of census information are that the data is readily available, and reliable. Because the census is undertaken every five years, possible population trends can be identified:

“...our community profile is pretty average for New Zealand...nothing's much changed over the past few years..."

The disadvantage of census data is that it provides only "background" information, which requires further interpretation as to its implications for library services in general, and collection development in particular. 
Study participants made use of the census data in their formal collection development policies, and as one of the foundations for their informal collection policies and practices.

For those institutions with formal written policies, the census figures were often presented as a "community profile" section of the document.

The ways in which population trends might impact on library collection use was also frequently stated in the formal policies:

"...these demographic trends have resulted in increasing demand on libraries by disadvantaged users..."

"Large print books are aimed at readers with failing eyesight and their popularity reflects our aging population..."

Data available from the census was used by participants to guide informal collection practices. For example, one participant was using figures from the census to help plan for the introduction of a library website:

"At the moment... something like 32\% of the [district's] population have got the net. That's something we've got through the statistics..."

Another participant regularly matched the age profile of the community, derived from the census, against the age profile of the library's database of registered 
borrowers, in order to obtain more detailed information about library customers. This information provided valuable data for collection planning:

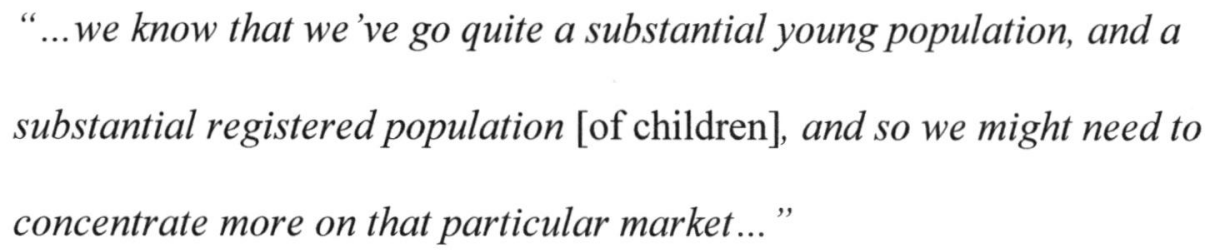

For public library managers, census data provides a valuable source of information about the community, and about actual and potential library customers. This data can lay a foundation for policy formulation, and for informal collection development practices and procedures.

\subsubsection{Council data-gathering activities}

Most study participants had access to, and made use of, information that had been compiled about their community by their parent institution. This data was often the work of the Council planning department, and built upon the demographic information available from Statistics New Zealand.

Some participants had also become involved in their parent institution's "Longterm Council Community Plan", which is mandated by the New Zealand Local Government Act 2002. 
The annual planning process undertaken by local authorities was used as a mechanism for policy refinement and information-gathering by some of the study participants.

Council data-gathering and planning activities are of value to the library managers because they generate data about the community which is more detailed than the census, and which can be used to predict future trends, which the census does not:

“...we have a planner... who feeds stuff through for us all the time...he's got a plan worked out that goes through to about the year $2010 . . . "$

"Council... had consultants do both a community needs analysis, and some work on an arts, culture and heritage strategy..."

Several of the study participants had benefited from being part of their Council's annual and long-term planning processes. Participation in these exercises helped with the refinement of library policies:

"We're contributing to the annual planning process at the moment... and talking about the strategic initiatives that we want to follow..."

Further, the opportunity offered to the community to provide feedback through the Council's annual planning process can yield data relevant to library planning. However, most participants admitted that in reality very little useful information is received through the annual plan process. 
The main disadvantage of Council-initiated data gathering and planning activities, as far as the study participants are concerned, is that they are often given very little say in decisions about the type of information that will be sought from the community. For example, one participant said that the library had no input into the types of questions that would be asked in a "community views" survey, which had been undertaken as part of that Council's long-term planning exercise.

For most participants, involvement in their Council's planning cycles presented a valuable opportunity to gather supplementary information about the community. The participants were aware of the need to exploit such opportunities, so that potential benefits for library policy formulation and application could be maximized.

\subsubsection{Surveys}

For the purpose of this study, the use of surveys as an "indirect" informationgathering technique refers to their use by agencies other than the library or the parent institution. When discussing this topic during the interviews, all participants made reference to the telephone survey of local authority districts which is undertaken by the National Research Bureau (NRB).

The purpose of this particular survey, which is usually conducted annually, is to measure the levels of community satisfaction with the full range of Council services, including libraries: 
“...the Council...is hooked into the Communitrack, the NRB survey, which is a much more general survey. It asks for general satisfaction, and people can comment and they do comment..."

The NRB survey enables the study participants to benchmark their library's result against other peer-group libraries nationally.

The main advantage of the NRB survey is that is uses a random sample from the community - those surveyed may, or may not, be library users. For some study participants, the NRB survey was the only method employed to consult with nonusers of the library.

The disadvantage of the NRB survey is that it is a very general survey, with only a few questions that relate to library services:

"Generally we haven't had much that's relevant to collection development..."

One participant expressed a lack of confidence in the survey methodology. A scrutiny of the list of telephone numbers used in the survey had revealed that many of the numbers didn't correspond to the geographic area of the district:

" 'Random' is the operative word...I wonder about the validity..." 
Another participant noted a further drawback to the NRB survey, which is that it only reports on negative feedback, and doesn't forward positive comments.

Outside surveys such as that held by the NRB do not directly contribute to public library collection development policies. However, the overall rating received from the survey can be an indication that the library is succeeding in meeting the community's needs:

“...we got a 98\% approval rating of the library services as 'good' or 'very $\operatorname{good}^{\prime} . .$.

\subsubsection{Research consultants}

Use of research consultants to gather data about customers and community was not widespread amongst the study participants. One participant had used outside consultants to process the data from user surveys, and two other participants had in the past used consultants to undertake a review of library services.

Research consultants can contribute a level of professional expertise that may not be available within the library or the parent institution. They also have an objective viewpoint. A research consultant had helped one of the study participants to develop skills which have been of ongoing value: 
“... with the library review... we used a consultant... he helped me in quite major ways...I did a whole series of benchmarking exercises with libraries of similar size... which was really interesting..."

The main disadvantage to the use of consultants is that they are costly to engage. Further, funding constraints may mean that the recommendations that they make are not carried out:

For one study participant, recommendations made by consultants directly related to the library's collection development policies and practices:

"...the review that was done recently for us...advised us to buy a great deal more non-fiction..."

Consultants have the skills and expertise which enable them to gather valuable information about the library community's needs; however, for most institutions, the cost of engaging their services makes them an infrequently-used technique.

\subsubsection{Circulation analysis}

Out of all of the techniques available to the study participants for obtaining information about community and customer needs, analysis of materials circulation data was the most extensively used, and probably the most relied upon. 
This method makes use of the data generated by the library's computerized circulation system to determine the usage of library collections:

"...one of the most useful tools is statistical analysis of the issue statistics...we can measure the issues of books in particular item areas..."

"...we look at how many of those are out on issue at any one time as a percentage, compared with how many books we have got on a different topic..."

"I look at the Deweys and look at the number of stock units, the annual number of issues, and what percentage of this collection is issuing on an annual basis..."

The advantages of analysis of circulation data as an indicator of customer needs include its immediacy:

“...if we're getting it right, we'd get reasonably good issues for those new items..."

The method also enables changes in informal purchasing policies to be assessed:

“...she's buying a lot more of the literary material, and that's doing quite well.." 
Customer trends can be identified by this method:

"...our usage data has been slightly declining over the last two years..."

One participant felt that circulation data was a good method to use for crosschecking the information gathered through community consultation:

"I think that we've got to check the results [of consultation] against the actual usage..."

A drawback to the circulation analysis methodology is that it is reliant on wellconfigured computer software:

"At the moment our programme is pretty old... and I actually have to do a lot of fiddling round myself..."

Another disadvantage is that materials circulation figures can be ambiguous, as one participant remarked:

"... is there heavy usage in this area because we haven't got enough of it, or is it... because we've bought lots of books, and they're new and shiny and look appealing... [We're] aware all the time that it can be both driven and lead..." 
Another participant acknowledged that it is often not advisable to rely solely on circulation data as an indicator that the library is meeting customer needs:

"... the review that was done recently for us... advised us not to worry too much about public response...not just using the issues as the sole arbiter of what we bought..."

All participants verified that analysis of circulation data has a direct and important link in the application of collection development policies, practices and procedures in their institutions.

One institution used a particularly complex type of analysis, whereby calculations were made as to the average annual issue frequency of items of stock in each subject category. An average of eight issues per item meant that the stock is achieving optimum usage prior to its depreciation over a period of ten years. Lower or higher issue rates were an indicator of inefficient use of stock.

Several institutions had a formal statement in their written policies setting out the role played by circulation analysis in collection development:

"This information helps selectors identify popular topics, pinpoint areas of weakness, gauge changing information needs, and develop the collection accordingly”. 
“The library's computer system accurately calculates the number of books borrowed from every section of the library on a daily, monthly, or yearly basis. These figures are an invaluable aid to collection development planning”.

11.2.6 Analysis of borrower activity data

In addition to providing comprehensive data about the usage of collections, library circulation systems also gather data about registered library users who borrow materials from those collections.

Several study participants discussed the ways in which they use this data, as a supplement to the issues statistics.

Borrower activity data was also used as a method for identifying non-users of the library:

“...we've got a fairly clear profile of who are not users from analysis of the correlation of the age of registered borrowers... and the population statistics of the city..."

Another participant compared the "gate-count" of the number of people who came into the library each day with the number of people who had used their library card to borrow books on that day, in order to demonstrate that $70 \%$ of customers who used the library weren't necessarily borrowers. 
Another participant received borrower usage statistics from a neighbouring library as a means of investigating customer behaviour patterns:
"[The city library] ... gives me statistics on how many people from out of the district use their library... and what the difference was between now, and, say, five years ago..."

The main advantage of borrower usage data is that, like circulation data, it is readily available through the library's computerized circulation system.

However, borrower usage data is not necessarily statistically valid, as one participant pointed out:

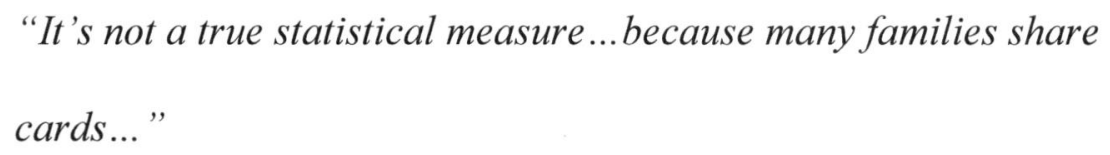

This data also requires interpretation in order to be meaningful for collection development policies. The following statement, from one of the library's policies, demonstrates that data gathered about borrowers often needs more in-depth investigation if its implications for collection development are to be meaningful:

"Twice as many issues to women as to men..."

As a method of gathering information about library customers and their needs, analysis of borrower activity is a useful, indirect tool. However, data gathered by 
this method is most valuable when used in conjunction with information gathered from other sources.

\subsubsection{Gate counts}

Gate count statistics are usually generated from a library's book security system, through which all customers visiting the library must pass.

As described in the above discussion, gate count statistics are usually used in conjunction with borrower card use as a method of gauging the numbers of people who are visiting the library.

As with the other types of automated data gathering, gate count figures are readily available to the study participants. However, these figures provide "raw" data only, which needs to be interpreted with reference to other data-gathering methods.

Gate count figures can have a role in collection development policies, because they may give some indication of the level of customer demand for resources that cannot be borrowed from the library, for example reference materials and newspapers. However, user surveys are probably a better method of gathering information about "non-borrowing" library customers. 


\section{$\underline{11.2 .8}$ In-house materials use}

Analysis of in-house materials usage was mentioned by some participants as being an "informal" method of measuring the usage of library collections. This data is:

“...anecdotal information, I guess, gathered by [staff] clearing up zones of the library...they'll see the same kinds of books left out on the desks..."

The main drawback to analysis of in-house materials use is that most institutions do not have a means of codifying this information:

“...we don't have a formal method of capturing that at the moment..."

If this type of information about collection usage could be recorded, it has the potential to usefully inform collection development activities.

11.2.9 Analysis of requested materials

All of the institutions in this study offer a service whereby library customers can request specific items from the collections, or can apply to interloan particular items from another library.

Most participants had a system for scrutinizing all materials requested in this way, in order to identify gaps in the library's collections: 
"We look very carefully at anything people want to interloan to see if there's a hole in the collection..."

The advantage of request analysis is that it is a method which provides regular feedback from customers about the library collections:

"Normally you'd expect two to ten borrower suggestions a week to come through about what you're buying...”

"We have reports that generate levels of reserves on things..."

The method also gives the library an easy option for responding to customer needs:

"We normally would buy them... [requested materials]"

A drawback to requests analysis is that, while it works successfully for library customers who know what they want from the library, it may work less well for customers who are less well-informed about their needs.

Study participants confirmed that analysis of requests plays an important role in their collection development policies. This may be stated informally:

“Just looking at what's getting reserved... see what's not getting reserved, so that definitely informs it..." 
"Regular library users often make suggestions, pointing out deficiencies in the collection or telling us about new books which we haven't caught up with..."

The role of requests analysis may also be elaborated in a formal policy statement, such as:

"Selectors will consider all suggestions for purchase..."

\subsection{Comparison of information gathering methods}

The following table (which is based on Data analysis chart 2, Appendix F) summarises the main points of the preceding analysis. This table enables comparisons to be made between public librarians' use of direct" consultative techniques, and their use of "indirect" data analysis techniques. 
Table 1: Comparison of information gathering methods

\begin{tabular}{|c|c|c|}
\hline & Community consultative methods & Data analysis methods \\
\hline Advantages & $\begin{array}{l}\text { In general terms, some of the main advantages of } \\
\text { consultative methods are that they: } \\
\text { - provide valuable feedback } \\
\text { - create goodwill } \\
\text { - can be informal } \\
\text { - involve personal contact with customers. }\end{array}$ & $\begin{array}{l}\text { Some of the advantages of data analysis methods are the } \\
\text { same as for consultative methods. Data is: } \\
\text { - easily gathered } \\
\text { - immediately available } \\
\text { - objective } \\
\text { - generated regularly } \\
\text { - a useful cross-check to consultative methods. }\end{array}$ \\
\hline
\end{tabular}




\begin{tabular}{|c|c|c|}
\hline & Community consultative methods & Data analysis methods \\
\hline Disadvantages & $\begin{array}{l}\text { The main drawbacks to community consultation methods } \\
\text { are that they: } \\
\text { - are costly } \\
\text { - can be time-consuming } \\
\text { - are reliant on good communication skills. } \\
\text { - the results can be difficult to codify. }\end{array}$ & $\begin{array}{l}\text { Data analysis methods also have drawbacks, which are that } \\
\text { they: } \\
\text { - can be costly } \\
\text { - have possible problems with validity } \\
\text { - produce data that needs interpretation. }\end{array}$ \\
\hline Frequency of use & $\begin{array}{l}\text { Some consultative methods are used only irregularly by } \\
\text { the study participants, while others are in continuous use. }\end{array}$ & $\begin{array}{l}\text { Most data analysis methods are regularly used by the study } \\
\text { participants. }\end{array}$ \\
\hline $\begin{array}{l}\text { Role in informing } \\
\text { collection development } \\
\text { policies }\end{array}$ & $\begin{array}{l}\text { The roles played by community consultation and data } \\
\text { analysis in the formulation and application of collection } \\
\text { development policies were regarded by most participants } \\
\text { as being fairly similar. However, consultation was seen } \\
\text { as playing a somewhat broader role, namely: } \\
\text { - to directly inform collection building and } \\
\text { purchasing decisions } \\
\text { - to help define the role of the institution in the } \\
\text { community } \\
\text { - to help define the institution's strategic focus. }\end{array}$ & $\begin{array}{l}\text { Data analysis methods were often used in conjunction with } \\
\text { each other by study participants. Their role in the } \\
\text { formulation and application of collection development } \\
\text { policies was: } \\
\text { - to directly inform collection building and } \\
\text { purchasing policies } \\
\text { - to help with planning for future collection } \\
\text { development. }\end{array}$ \\
\hline
\end{tabular}




\subsection{Formal collection development policies}

A definition for the term "collection development policy" was provided in the literature review section of this report. In this section of the analysis, the data gathered from the study participants about formal policies will be discussed under the following topic headings:

- their importance in the participants' institutions

- the functions that they fulfill

- the advantages of formal policies

- the disadvantages of formal policies

- the ways in which the policies are applied to materials selection activities

- the link between community consultation and data analysis, and policy formulation and application.

\subsubsection{Importance of formal policies}

Study participants' opinions varied as to the importance of a formal collection development policy document.

Some participants, even though they had compiled such a document, didn't accord it a great deal of importance:

"I think it's overrated, actually. You get some people who say 'this is a very important ...core part of ...it's not!" 
"I can't even remember what I've called it now. But it's something I did for council...it's somewhere..."

Another participant, who was formulating a policy for the first time, acknowledged its potential value:

"I just want to keep working away at it to try and get something that works, that we can use..."

A third participant succinctly summed up the value of a formal policy document:

"Your community expects that you're spending money responsibly, that you know what you're doing, that you've got professional staff, that you've got systems in place. So you need to have some kind of documentation there..."

\subsubsection{Functions of formal policies}

The functions that formal collection development policies fulfilled in the participants' institutions corresponded very closely to those that are identified in the literature.

For one participant, the document was being used politically, as a means of communication with the institution's funding provider:

"Mostly for political reasons... if we're going to maintain funding, then we need to have a policy that's accepted by Council..." 
Another used the policy as a means of stating collection development principles to their funding provider:

"Ifeel it's important that Council knows what principles we're buying books on..."

Yet another participant described their policy as creating "boundaries or parameters" within which the library operates. Another described it as:

"... a framework within which we work..."

Participants' formal policies were also used as a means of communicating with their communities and their customers:

"...so we can explain to borrowers why we may not be buying in particular $\operatorname{areas} \ldots ”$

"You often need a document to protect yourself against people who might have funny ideas..."

One participant explained how their policy had been used for "risk management" - as a way of defending the library's decision to establish a video collection against a challenge by a commercial operator in the town. 
Participants also acknowledged the value of a formal policy document in providing guidance for staff:

“...it's also a training document...it's really useful for new staff..."

“...if we had more of a [staff] changeover, there'd be more impetus to have stuff formalized..."

One participant's policy included a clear "purpose statement". To quote directly, the policy:

- "...represents a formal commitment to the collection,

- helps establish priorities for the allocation of funds and commits the library to serving all sections of the community,

- enables the library to be accountable to Council management, Councillors and ratepayers,

- assists the staff in responsible expenditure of funds,

- provides a guide to buyers in specific subject areas and enables staff to focus on what the library is acquiring, for whom, and for what purpose,

- provides a guide to users as to what they can expect to find in the collection..." 


\subsubsection{Advantages of formal policies}

The researcher concludes that the main advantage for study participants in having a formal collection development policy must be that such a document is readily available to fulfill a variety of roles within the institution.

For those participants who were in the process of drafting or revising their documents, policies developed from other institutions could be used for guidance:

“...we've stolen a lot of work that we like...that we're happy with... which fits the way we want to develop our collections..."

Another advantage to a formal policy is that it can be written in very general terms, thus increasing its ease of preparation:

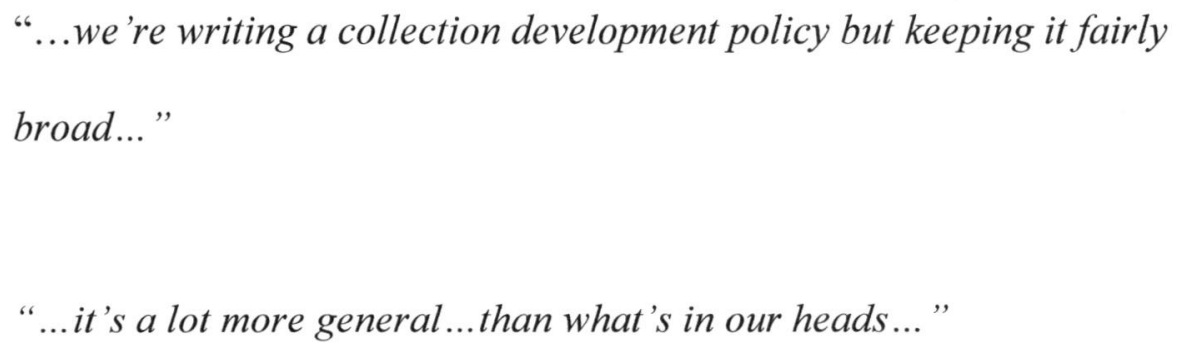

11.4.4. Disadvantages of formal policies

The main drawbacks to formal policies, as perceived by the participants, are that they are difficult and time-consuming to write, and may prove unnecessarily restrictive: 
“...it's a slow process to do it..."

“...our library is really, really busy... so policy stuff tends to be a bit of a side issue really..."

“...if you do it in too much detail it can get quite limiting..."

\subsubsection{Frequency of revision}

One of the policy documents contained a specific statement as to how often it is to be revised:

"This policy should be reviewed and updated no less frequently than every five years.”

However, several participants' policies were only available in draft format, or were currently under revision:

"...we have a draft one that we're working through at the moment..."

"...it's the first time that we've formalized it in any way..."

Most participants wrote the policies themselves, with possibly some input from other library staff: 
'"...every couple of years I need to look at that [the policy] and compare it with what I've been doing every year..."

"...it would be a team effort, looking at things and talking about what needs to be reviewed..."

\subsubsection{Application of policy to materials selection}

The study participants' formal policies all contained explicit statements about the way materials selection will operate in those institutions:

"The head of libraries is responsible for managing the selection of books and other materials. A team of librarians, including the branch librarians, will help with selection."

“... [The library] endorses the principle of intellectual freedom. We do not condemn or endorse opinions and views expressed in materials within our collections. We aim to develop collections which express a diversity of views and opinions."

However, the extent to which policy determines practice, or is simply a reflection of it, was not clarified by the study participants. An example of the latter situation was given by one participant, who explained that the development of electronic resources within their institution had occurred quite rapidly, resulting in the need for the 
collection development policy document to be updated, so that it reflected current practices.

11.4.7 Role of community consultation and data analysis in policy formulation and application

Most participants were not able to confirm that their collection development policies contained a specific commitment on behalf of the institution to meet the information needs of the community.

However, the researcher did find that the policy documents usually contained a general statement to this effect, such as the following example:

"Collections will be developed to include information to reflect the community's backgrounds, cultures, attitudes, interests, and tastes".

\subsection{Informal collection development policies}

Throughout this study, the term "informal policy" is taken to mean the unwritten policies, practices and procedures which inform an institution's collection management activities. 
As with the previous section on formal policies, analysis of the data about informal policies will address the following sub-themes:

- importance

- functions

- advantages

- disadvantages

- frequency and method of revision

- role in materials selection

- link between community consultation and data analysis and policies

\section{$\underline{\text { 11.5.1 Importance of informal policies }}$}

Most study participants, particularly those in the smaller institutions, felt that informal collection development policies are more important than formal ones:

“... the bulk of what you're using to select your stock in a small library like ours is better off in somebody's head..."

One of the larger institutions had documented several of its collection practices and procedures. However, these were regarded as "in-house" documents which were separate from the formal collection development policy. 


\subsubsection{Function of informal policies}

Participants did not specifically discuss the functions that informal collection development policies play within their institution. However, the researcher's observation is that these policies are used as the basis for the institutions' day-to-day collection development activities.

One participant was able to give an example of an informal policy direction which was guiding that institution's collection development:

"... as far as the library at the moment is concerned... we're working towards the...education and recreation strategic goals..."

\subsubsection{Advantages of informal policies}

Most study participants preferred to use informal policies to guide their collection management activities, even though their institution may have had a formal policy document.

Informal policies were regarded by the participants as having several advantages. There are several reasons for this. Firstly, informal policies have the advantage of flexibility:

"... a rigid collection development policy would be my biggest nightmare..." 
Secondly, participants felt that informal policies allow the institutional and community knowledge of long-serving staff members to be utilized:

Thirdly, participants felt that informal policies allow room for the exercise of professional expertise:

“...you have to make... an executive or professional judgment..."

More than one participant discussed with the researcher the difficulty of trying to achieve a balance in collection-building between "what people want to read" and "what people should be reading". This dilemma demonstrates the type of ambiguous situation to which informal policies are ideally suited, according to the participants:

"...we're not trying to codify that in the collection development policy...we don't feel it can be..."

\section{$\underline{\text { 11.5.4 Disadvantages of informal policies }}$}

The major disadvantage to not having a written collection development policy, as identified by the participants, is that if such a policy is required, it's not there:

"... if I was run over by a bus tomorrow...then there would be a problem..."

Those participants who had done some work towards recording their informal policies, but who had not yet completed the task, agreed that until they completed 
their policy document, there would be no formal record of the work they had done to date:

“...we've got a log of informal work that we've done, but we haven't codified it yet..."

"...we haven't got a lot of it formalized or written down yet..."

\subsubsection{Frequency of revision}

It was clear to the researcher during the interviews that the informal policies at the participants' institutions were being constantly revised. The facility with which these types of policies can be revised, reviewed, altered and updated is their primary characteristic:

"...we do have policy documents, but they tend to be kind of under review... or informal..."

11.5.6 Application of informal policies to materials selection

In an institution that operates informal collection policies, the criteria that are used for materials selection are entirely practice-based. 
Most study participants' selection criteria had been developed from the professional knowledge and training of the staff, as well as from the staff's knowledge of the library's collections and of the community:

“...it's more based on practice...there's currently no overall policy..."

“...it's done by a group of senior staff, and it tends to rotate..."

“...our collection management is handled by twelve difference people ...we don't have an overall collection manager..."

“...the buyers that we've got have been with us for a long time...they know what we've got..."

Most of the library managers interviewed had responsibility for the overall direction of collection development. However, one institution had recently established a collection management librarian position for this purpose.

11.5.7 Role of community consultation and data analysis in policy formulation and application

The fact that their institutions were developing collections which meet the needs and wants of their communities was taken for granted by most participants: 
“...if I'm not meeting the needs of the community, then what ... am I doing here. Some things are obvious..."

One participant stated a conviction that the information-gathering activities their institution is currently engaged in provide the library with "good solid data" about the nature of the community. The researcher gained the impression that most participants feel that they are well-informed about their community and their customer needs, and that they have a good foundation of knowledge upon which to base their informal collection development policies, practices and procedures.

\subsection{Summary of the role played by information-gathering techniques in policy formulation and application}

The following table (based on Data analysis chart 4, Appendix F) offers a synthesis of the material presented in the data analysis and interpretation section of this report. 
Table 2: Summary of the role played by information-gathering techniques in policy formulation and application

\begin{tabular}{|c|c|c|}
\hline Method: & $\begin{array}{l}\text { What community/customer needs does this method } \\
\text { help to identify? }\end{array}$ & $\begin{array}{l}\text { What role does this method play in collection } \\
\text { development policy formulation and application? }\end{array}$ \\
\hline User surveys & Identifies the needs and wants of current library users & Informs collection development \\
\hline Focus groups & $\begin{array}{l}\text { Identifies the needs and wants of current and potential } \\
\text { library users }\end{array}$ & $\begin{array}{l}\text { Has the potential to provide information for collection } \\
\text { development }\end{array}$ \\
\hline Formal committees & $\begin{array}{l}\text { Can identify the requirements of the community, from } \\
\text { a political perspective }\end{array}$ & $\begin{array}{l}\text { Can assist with the formulation of collection development } \\
\text { policies }\end{array}$ \\
\hline Liaison with schools & Identifies the needs of school-age children & $\begin{array}{l}\text { Provides information for collection development in the } \\
\text { children's library }\end{array}$ \\
\hline $\begin{array}{l}\text { Liaison with tertiary } \\
\text { institutions }\end{array}$ & Identifies the needs of students, of all ages & $\begin{array}{l}\text { Informs collection development and/or collection } \\
\text { development policies }\end{array}$ \\
\hline Staff feedback & Identifies the needs of individual customers & Informs purchasing decisions \\
\hline $\begin{array}{l}\text { Comments and } \\
\text { complaints }\end{array}$ & Identifies the needs and wants of individual customers & Informs purchasing decisions \\
\hline
\end{tabular}




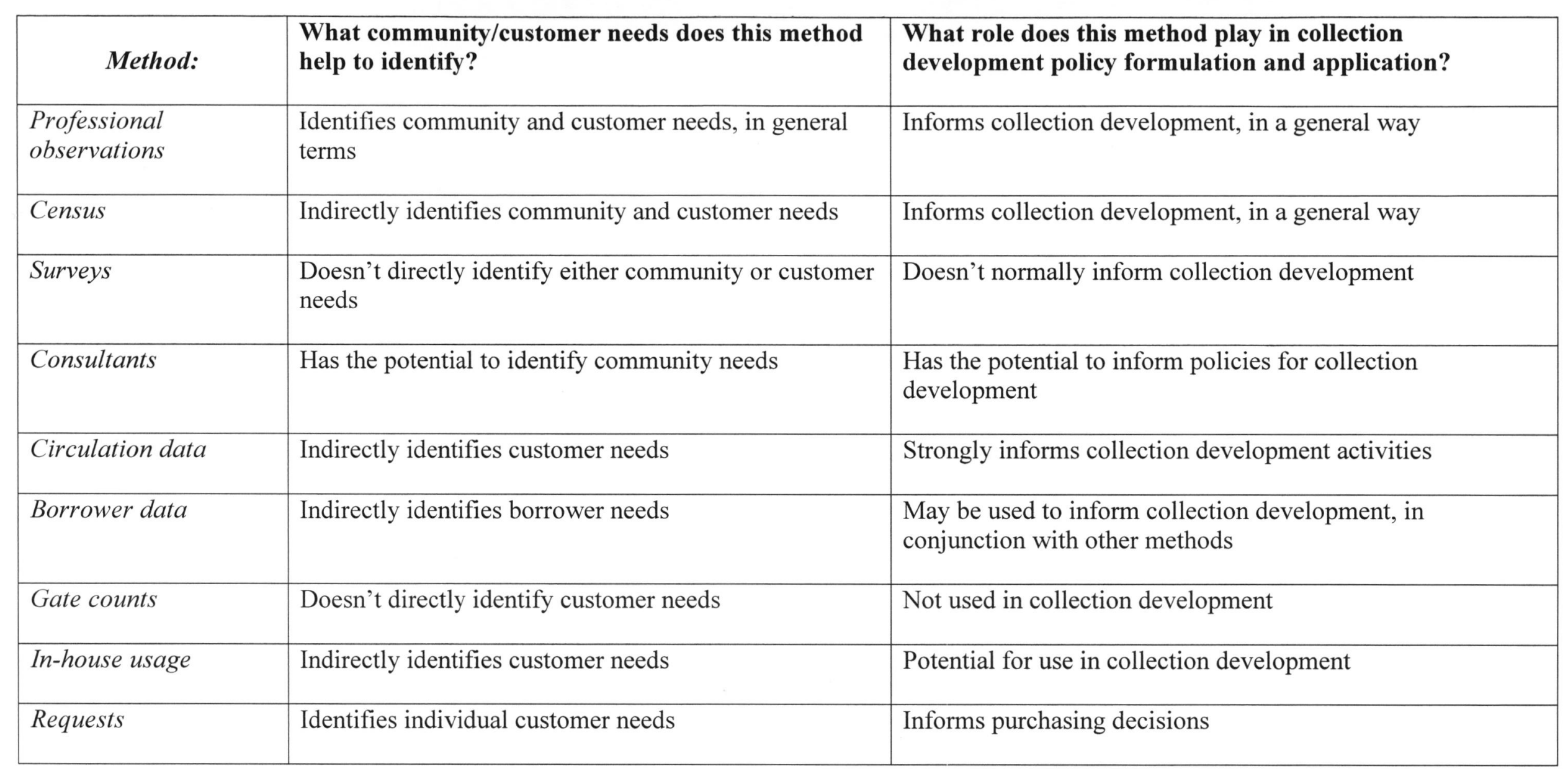




\section{Summary and conclusions}

\subsection{Relating the findings to the original conceptualization of the problem}

The intention of this research study, as outlined in the introductory sections to this report, was to investigate the consultative processes that were used by a sample of public library managers during the formulation and application of their institution's collection development policies.

The researcher envisaged that public library managers would be engaging in community consultation as part of the policy formulation process, in order to ensure that their libraries' collections remained responsive to community needs.

The researcher also wondered whether the New Zealand Local Government Act 2002, with its emphasis on community consultation by local authorities, might be influencing public library managers' attitudes towards the value of consultative processes.

The researcher further envisaged that collection development activities might follow a cyclical process, whereby community needs and wants are identified, collection development policies are formulated to address those needs, and finally, the policies are given practical application through the library's collection development activities.

Through a review of the literature, the researcher had identified a variety of techniques, both "direct" and "indirect" that a library manager can use for the purpose 
for gathering information about community and customer needs. In management theory, these techniques are collectively referred to as "community needs analysis".

The researcher's primary aim was to investigate the application of community consultative techniques in New Zealand public libraries, but the scope of the study also included an examination of the application of data analysis methodologies.

The researcher did not have a prior expectation that the study participants' institutions would have a formal, written collection development policy. In the absence of such policies, the researcher was interested to examine the role of informal collection policies, practices and procedures within the institutions chosen for the study.

The findings of the study accord with its conceptualization in many respects. All of the participating institutions did have a collection development policy (although in some cases this document was in a draft stage). Further, all participants did currently engage, or had engaged in the past, in a range of community consultative activities (although these might not necessarily have been undertaken specifically for collection development purposes).

However, the findings of the study differed in several respects to the way in which collection development policy formulation and application had been conceptualized in the research proposal. These differences are outlined briefly below, and will be discussed in more detail in the following section of this report. 
1. The process of policy formulation was less well-structured and methodical than the descriptions in the international literature.

2. The use of community consultative processes by public library managers was undertaken less frequently, and was less well-developed, than the descriptions in the international literature.

3. Data analysis was the information-gathering methodology of choice for public library managers, which is not the case in the professional literature.

4. Informal policies, practices and procedures (both written and unwritten) provided the framework, in all of the institutions studied, for day-to-day collection management activities.

5. Formal collection development policies occupied a peripheral position in the collection management function of the libraries in this study.

The researcher's interpretation of the study findings can be represented by means of the diagram on the following page: 


\section{Figure 2: Diagram of public library collection development}

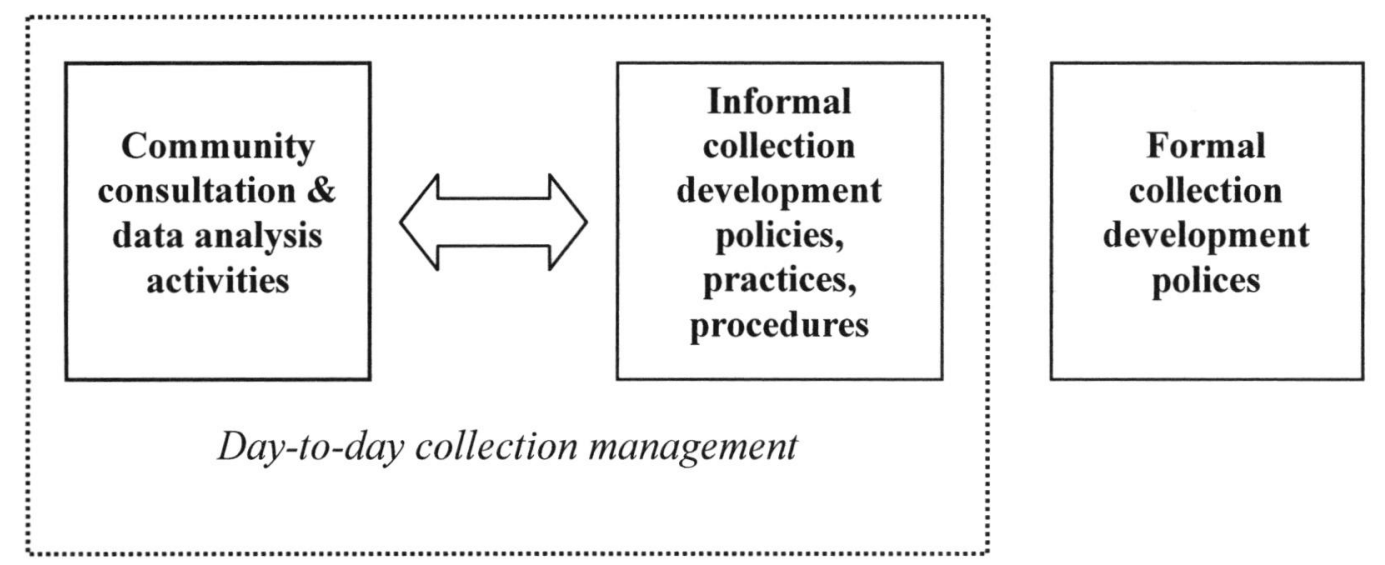

As this diagram illustrates, community consultative and data analysis activities are carried out by the study participants. Some of these techniques, such as focus groups, are utilized only occasionally, whereas others, such as schools liaison and circulation analysis, are undertaken regularly.

The information gathered by community consultative and data analysis methodologies provides the framework for the libraries' informal collection development policies, practices and procedures. Informal policies, in turn, determine the need for further information-gathering.

For example, discussion with the representatives of different ethnic groups in the community may highlight the need for the library to develop resources for these groups. A commitment to develop resources for new migrants in the community becomes one of the library's informal collection development policies. The library then undertakes ongoing liaison with the ethnic groups, to ensure that collections are developed which best meet their information needs. 
The peripheral position occupied by formal collection development policies amongst the study's participants is not easily explained by the researcher, particularly in light of the fact that all participants did have, or were working on, a formal policy document.

Part of the explanation could be that formal collection development policies are seemingly, in the words of one participant, "not fashionable". Contemporary local authority managers are required by their parent institution to prepare a variety of planning documents: business plans, annual plans, strategic plans. Possibly the multitasking managers of medium-sized public libraries simply do not have the resources available to ensure that a formal collection development policy lies at the heart of responsive collection management practices in their institution.

\subsection{Recommendations for professional practice}

As a result of undertaking this study amongst a sample of medium-sized New Zealand public library managers, the researcher has been able to identify a set of characteristics that are indicative of "best practice" in collection management.

In the researcher's opinion, New Zealand public libraries practicing responsive collection management demonstrate the following:

- the library has a written collection development policy, which plays a key role in the institution's day-to-day collection management function, 
- this policy has been formulated as a result of research into what the library's community and customer base need and want from the library's collections,

- this research has been undertaken using a variety of community consultation and data analysis techniques, and

- the research into community and customer needs is ongoing, to ensure that the library's collection management practices remain responsive to those needs.

In the previous section, the researcher indicated that there were several respects in which the findings from this study differed from the way in which collection development policy formulation and application is described in the international professional literature.

These differences are discussed in more detail in this section, in conjunction with recommendations which the researcher offers for consideration by the New Zealand public library profession.

The issues which have arisen are: the process of policy formulation; the use of community consultation; the reliance on data analysis; the role of informal policies; and, the relative importance of formal policies.

In each of the following subsections, the researcher will present a suggested recommendation, followed by an explanation of the reasons for this recommendation. 


\subsubsection{The process of policy formulation}

\section{Recommendation: That public library managers take a systematic approach towards the formulation and revision of their libraries' collection development policies.}

The researcher found that amongst the public library managers who participated in this study, the process of policy formulation was less well-structured than that described by the literature. It appeared to the researcher that these managers had not undertaken policy formulation in a methodical, step-by-step way. Nor had the participants used community needs analysis techniques as an integral part of the process. Furthermore, only one institution had used a committee, or team, of people to assist with the policy formulation process.

The researcher suggests that the managers of medium-sized New Zealand public libraries may wish to adopt a more systematic approach when embarking upon the formulation, or revision, of their collection development policy. Guidelines for this type of approach towards policy formulation are outlined in the professional literature, with Cassell and Futas (1991) providing a particularly relevant example.

New Zealand public library managers may wish to follow the practice of their United States counterparts, and establish a library committee or planning team to assist with writing their library's collection development policy. Members of the community with whom the library has already established consultative links could be invited to participate in this project: friends of the library, representatives from a variety of 
special-interest groups, representatives from the Maori community, staff from local schools and polytechnics, and library customers with a known interest in libraryrelated matters. Library staff, both senior and junior, may also be interested in becoming involved.

Once such a group has been established, a project timetable could be devised. The project's first step could involve an analysis of community and customer needs, using several of the techniques, both "direct" and "indirect", which have been identified throughout this study.

By adopting the structured approach towards collection development policy formulation that is recommended by the international literature, New Zealand public library managers may find that benefits accrue to all concerned: the library gathers first-hand information about the community's needs and wants; and members of the community become involved in the work of the library, thus creating goodwill for the future.

12.2.2 The use of community consultation

\author{
Recommendation: $\quad$ That public library managers use a broad range of \\ consultation techniques to gather information about community and \\ customer needs.
}

A second point of difference between the study's findings and the professional literature relates to the types of community consultation that were carried out by the 
participants, and the frequency with which the various methods were employed. Some participants indicated to the researcher that they felt they lacked the skills, and also the budgetary resources, to successfully manage the more complex consultation mechanisms. Others expressed doubts about the usefulness of information gathered through direct community consultation.

The data analysis section of this report explored the community consultation techniques that operated successfully within the study participants' institutions. The participants made widespread use of community liaison techniques, particularly in their relationships with educational institutions, special-interest groups, and Maori. Participants also made extensive use of the staff feedback technique, encouraging staff rostered on service desks to note any feedback about the library's collections that may be received from customers during the course of daily transactions. Most of the library managers had established comments and complaints procedures in place, both of a formal and informal nature, and made good use of their own and their staff's "local knowledge" of the community.

However, the researcher discovered that two important methods of community consultation identified in the literature - library surveys (of both users and non-users) and focus groups - were not well-used by the study participants. Only one of the participant's institutions undertook a regular survey of library customers, and none had attempted a survey of non-users of the library. Although many of the participants had experience of holding focus group sessions, none did so regularly. 
Table 1 in the data analysis section summarized participants' opinions about the benefits that can result from community consultation initiatives. Amongst these benefits are: goodwill generated, immediately-available information, and personal contact between library staff and members of the community.

Focus groups, in particular, demonstrate these advantages. Another advantage of the focus group technique is that it facilitates the gathering of information from people who may not currently be users of the library, and from other groups in the community whose information needs might otherwise be difficult to assess.

The other little-used technique, library surveys, has the important advantage of being able to identify trends in the community's changing information needs. In order for the technique to be its most effective, surveys should be carried out at regular intervals.

The researcher would recommend that New Zealand public library managers consider using a broader range of community consultation techniques than they do at present. Regular use of a variety of techniques could ensure that in-depth information is gathered from a wide cross-section of people in the community

In embarking upon techniques with which they are unfamiliar, librarians could possibly follow the example set by some of the participants in this study. Several participants had engaged a skilled facilitator to guide their focus group discussions, and another had sought assistance from a researcher at the university to help devise survey questions, and analyse the resulting survey data. 


\subsubsection{Reliance on data analysis}

\section{Recommendation: That public library managers continue to analyse the data they receive from various sources to inform collection management decisions, but that they give consideration to balancing this information with that gathered by consultative processes.}

The professional literature recommends 'indirect' data analysis techniques as providing a valuable source of information for library collection management purposes. The techniques that have been explored during the course of this study are: use of census data, use of data produced by the parent council, surveys conducted by outside agencies, and analysis of circulation data, borrower requests, gate counts and in-house materials usage.

The researcher found that the study participants demonstrated a skilled understanding of data analysis methodologies. Analysis of circulation data enabled them to be wellinformed about the performance of their library's collections, and about borrower patronage patterns. Participants made good use of statistical data about their community available through the census, scrutinized supplementary demographic information produced by their parent council, and analysed feedback about the library's performance received through the National Research Bureau survey. The library managers also perused other available in-house data, such as requests for materials and gate-count figures, for the additional information about customer needs that this might provide. All of the information gathered through "indirect" 
methodologies was applied by the participants in their library's collection development policies and procedures.

However, the researcher feels that the practices of the study participants did not correspond with those recommended in the professional literature in the following respects: 1 . with regard to the emphasis that was placed by the participants upon the importance of data analysis techniques, and 2. in relation to the extent to which the participants relied upon the information gathered by these methods to inform collection management decisions. The extent to which the participants relied upon circulation data was particularly evident to the researcher.

The researcher would suggest that New Zealand public library managers possibly need to give greater acknowledgement to the fact that the techniques they prefer for gathering information about customer and community needs are, by their very nature, "indirect". The managers could also possibly address the low priority accorded to some community consultation methodologies within their institutions. The researcher would suggest that a complementary use of "direct" and "indirect" informationgathering techniques might produce better outcomes for collection development practices than the libraries' current approach.

12.2.4 The role of informal collection development policies

Recommendation: That public library managers give thought to documenting their libraries' informal collection development policies, practices and procedures. 
The researcher's conceptualization of the role that informal collection development policies play in the study participants' institutions was illustrated by Figure 2 in the previous section of this report. During the course of the interviews, it became apparent to the researcher that most institutions relied upon informal collection development policies, practices and procedures to guide their day-to-day collection management activities.

Participants from the smaller institutions in the study were the most likely to have informal policies, practices and procedures "in their heads". Participants from the larger institutions were the most likely to have procedural documents for collection management activities, and may also have codified some of their informal policies in writing.

The international literature on collection management, for example Gorman and Kennedy $(1992,23-35)$ recommends that a library's collection development practices and procedures be outlined in written statements, which form a separate section of the collection development policy document.

The researcher would suggest that the managers of non-metropolitan New Zealand public libraries give consideration to the desirability of documenting all of their libraries' collection management practices and procedures. Consideration could also be given to reviewing their institutions' existing documentation, to ensure that it reflects current library practices. 
Written procedural documents can help to ensure continuity in collection management practices, despite staff turnover. A written procedural manual that is linked to the library's collection development policy can also help the library to re-position the policy at the centre of its day-to-day collection management activities.

\title{
12.2.5 The importance of formal collection development policies
}

\author{
Recommendation: That public library managers review the current status \\ of their collection development policy, with the aim of assigning this \\ document a more central role in their libraries' collection management \\ activities.
}

Library studies texts written on the subject of collection management recommend that libraries have a formal, written collection development policy. The benefits of such a policy were summarized in section 3.3 of this report's literature review. Many professionals concede, however, that in practice libraries frequently operate without such a policy. Evans $(2000,69)$ makes this point through the recounting of a humorous anecdote. This researcher has concluded that the peripheral position occupied by the collection development policies in the study participants' institutions probably does not differ greatly from professional practice elsewhere.

The researcher nevertheless recommends that non-metropolitan New Zealand public library managers take steps to address the issue of the status of their institution's formal collection development policy. Collection management in their library could benefit from the completion of a policy which is in draft format, or currently under 
revision. Other managers possibly need to give consideration to the currency and relevance of their existing policy, and make a commitment to review it at regular intervals.

To maximize the usefulness of a collection development policy, library managers should ensure that the document is written in language that can be easily understood by a variety of potential audiences. The policy can then be made readily available for consultation by library customers, councillors, library staff, and any other interested members of the community.

\subsection{Implications for further research, with reference to the limitations of the present study}

The two most important limitations of the current study are:

- The small size of the sample, and

- The restriction of the study to medium-sized, non-metropolitan public libraries.

Because five institutions only participated in this study, and because the interview methodology used has the potential for bias, the findings outlined in this report are not able to be generalized to the New Zealand public library population as a whole. The researcher would suggest two possibilities for further research, both of which would serve to broaden understanding of the role of community consultation in 
collection development policy formulation and application in public library practice throughout New Zealand.

1. A survey questionnaire that could be administered to all public library managers in New Zealand whose institutions served populations of between 30,000 and 70,000. This questionnaire would be based upon the present study's findings. (For sample survey questions, see Appendix G, 133). A quantitative analysis of questionnaire responses would determine the extent to which the findings of the current study are applicable to peer-group libraries throughout New Zealand.

2. A further series of in-depth interviews could be held, in this case with public library managers in metropolitan areas, serving populations of over 100,000. This study would use the same methodology as the current study, and its findings could help to determine the extent to which collection development practices in metropolitan institutions are similar to, or differ, from those of the non-metropolitan libraries.

Another possible avenue for future research could involve a more comprehensive investigation into the use of community consultative techniques by New Zealand public libraries. This research could help to identify the factors which contribute to successful consultation, as a means of encouraging more widesnręad use of these techniques among the profession. An initial requirement for this research would involve the identification of sites which are known to be operating well-established consultative mechanisms. 
13. Proposed and actual timetables for the project

13.1 Proposed timetable

13.2 Actual timetable

(Please see Gantt charts on the two following pages.)

WORD COUNT: 20,644 
13.1 Proposed timetable

\section{Research Project: Consulting the community ...}

Project start date: 10 November 2003

Project completion date: 16 February 2004

\begin{tabular}{|c|c|c|c|c|c|c|c|c|c|c|c|c|c|c|c|}
\hline & \multicolumn{15}{|c|}{ Week Number } \\
\hline Task: & Days & 1 & 2 & 3 & 4 & 5 & 6 & 7 & 8 & 9 & 10 & 11 & 12 & 13 & 14 \\
\hline 1. Meet with supervisor & 1 & & & & & & & & & & & & & & \\
\hline 2. Revise research proposal & 15 & & & & & & & & & & & & & & \\
\hline 3. Complete HEC application & 5 & & & & & & & & & & & & & & \\
\hline 4. Contact interview participants & 5 & & & & & & & & & & & & & & \\
\hline 5. Prepare interview schedule & 5 & & & & & & & & & & & & & & \\
\hline 6. Conduct pilot interview & 2 & & & & & & & & & & & & & & \\
\hline 7. Conduct interviews & 13 & & & & & & & & & & & & & & \\
\hline 8. Transcribe interviews & 15 & & & & & & & & & & & & & & \\
\hline 9. Return reports to participants & 15 & & & & & & & & & & & & & & \\
\hline 10. Analyse data & 15 & & & & & & & & & & & & & & \\
\hline 11. Write draft report & 13 & & & & & & & & & & & & & & \\
\hline 12. Submit draft to supervisor & 5 & & & & & & & & & & & & & & \\
\hline 13. Revise report & 5 & & & & & & & & & & & & & & \\
\hline 14. Submit final report & 1 & & & & & & & & & & & & & & \\
\hline
\end{tabular}

Notes: $\quad \mathrm{Xmas} / \mathrm{NY}$ holiday period weeks $7 / 8$

Duration of tasks has been calculated for a 5-day week, although work will also be undertaken during weekends 


\subsection{Actual Timetable}

\section{Research Project: Consulting the community ...}

Project start date: 10 November 2003

Project completion date: 16 February 2004

\begin{tabular}{|c|c|c|c|c|c|c|c|c|c|c|c|c|c|c|c|}
\hline & \multicolumn{15}{|c|}{ Week Number } \\
\hline Task: & Days & 1 & 2 & 3 & 4 & 5 & 6 & 7 & 8 & 9 & 10 & 11 & 12 & 13 & 14 \\
\hline 1. First meeting with supervisor & 1 & & & & & & & & & & & & & & \\
\hline 2. Revise research proposal & 15 & & & & & & & & & & & & & & \\
\hline 3. Complete HEC application & 7 & & & & & & & & & & & & & & \\
\hline 4. Contact interview participants & 3 & & & & & & & & & & & & & & \\
\hline 5. Prepare interview schedule & 3 & & & & & & & & & & & & & & \\
\hline 6. Conduct pilot interview & 1 & & & & & & & & & & & & & & \\
\hline 7. Conduct interviews & 9 & & & & & & & & & & & & & & \\
\hline 8. Arrange interview transcriptions & 12 & & & & & & & & & & & & & & \\
\hline 9. Return transcripts to participants & 8 & & & & & & & & & & & & & & \\
\hline 10. Analyse data & 8 & & & & & & & & & & & & & & \\
\hline 11. Write draft report & 13 & & & & & & & & & & & & & & \\
\hline 12. Submit draft to supervisor & 5 & & & & & & & & & & & & & & \\
\hline 13. Revise report & 5 & & & & & & & & & & & & & & \\
\hline 14. Submit final report & 1 & & & & & & & & & & & & & & \\
\hline
\end{tabular}

Notes: $\quad$ Xmas/NY holiday period weeks 7/8

Duration of tasks has been calculated for a 5-day week, although work will also be undertaken during weekends 


\section{Bibliography}

Baker, Sharon L., and Karen L. Wallace. 2002. The responsive public library: How to develop and market a winning collection. Englewood, Colo.: Libraries Unlimited.

Biblarz, Dora, Stephen Bosch, and Chris Sugnet eds. 2001. Guide to library user needs assessment for integrated information resource management and collection development. Lanham, Maryland: Scarecrow Press.

Cassell, Kay Ann, and Elizabeth Futas. 1991. Developing public library collections, policies, and procedures: A how-to-do-it manual for small and medium-sized public libraries. New York: Neal-Schuman Publishers.

Christchurch City Libraries collection development policy. http://library.christchurch.org.nz/Policy/CollectionDevelopment/Information/ [Accessed 2 August 2003]

Clayton, Peter, and G.E. Gorman. 2001. Managing information resources in libraries: Collection management in theory and practice. London: Library Association Publishing.

Cresswell, John W. 2003. Research design: Qualitative, quantitative and mixed methods approaches. $2^{\text {nd }}$ ed. Thousand Oaks, Ca.: Sage Publications.

Dienes, Frances. 1989. Collection development policies: Are they a good thing or a necessary evil? New Zealand Libraries 46 (2/3): 5-9.

Evans, G. Edward, and Margaret R. Zarnosky. 2000. Developing library and information center collections. $4^{\text {th }}$ ed. Englewood, Colo.: Libraries Unlimited.

Farmer, L.S.J. 2001. Collection development in partnership with youth: Uncovering best practices. Collection Management 26 (2): 67-78.

Frank, Donald G. et al. 1993. The relevance of collection development policies: Definition, necessity, and applications. $R Q 33$ (1): 65-74.

Finch, Helen. 1990. Analysing qualitative material. In Research methods in library and information studies, edited by Margaret Slater, 128-146. London: Library Association.

Friend, Frederick J. 2000. Policy: politics, power and people. In Collection management, edited by G.E. Gorman, 45-58. London: Library Association Publishing.

Gill, Philip. 2001. The public library service: IFLA/UNESCO guidelines for development. Munchen: K.G. Saur. 
Gorman, G.E., and J. Kennedy. 1992. Collection development for Australian libraries. $2^{\text {nd }}$ ed. Wagga Wagga, N.S.W.: Centre for Information Studies, Charles Sturt University.

Gorman, G.E., Peter Clayton et al. 1997. Qualitative research for the information professional: A practical handbook. London: Library Association Publishing.

Intner, Sheila S. 2002. Ten steps to great collections. Technicalities 22 (4): 5-7, 24.

Johnson, Peggy. 1994. Collections development policies: A cunning plan.

Technicalities 14 (6): 3-6.

Johnson, Peggy. 1997. Collection development policies and electronic information resources. In Collection management for the $21^{\text {st }}$ century: A handbook for librarians. G.E. Gorman, Ruth H. Miller, 83-104. Westport, Conn.: Greenwood Press.

Jones, Chris. 2001. Development strategies for library collections in a digital environment. Australasian Public Libraries and Information Services 14 (3): 101107.

The Knowhow guide to decision making: Under the Local Government Act 2002. 2003. Wellington, N.Z.: New Zealand Society of Local Government Managers; Local Government New Zealand; Department of Internal Affairs.

Leedy, Paul D., Jeanne Ellis Ormrod. 2001. Practical research: Planning and design. $7^{\text {th }}$ ed. Upper Saddle River, N.J.: Merrill Prentice Hall.

Local Government Act 2002. 24 December 2002. http://legislation.govt.nz/browse [Accessed 2 August 2003]

Local Government New Zealand: te Pütahi Matakokiri. 2001. http://www.lgnz.co.nz [Accessed 29 September 2003]

Morris, Ann, and Elizabeth Barron. 1998. User consultation in public library services. Library Management 19 (7): 404-415.

Mauch, James E., and Namgi Park. 2003. Guide to the successful thesis and dissertation: A handbook for students and faculty. $5^{\text {th }}$ ed. New York: Marcel Dekker.

Munroe, Mary H., John M. Haar, and Peggy Johnson eds. 2001. Guide to collection development and management, administration, organization and staffing. Lanham, Maryland: Scarecrow Press.

Nelson, Sandra. 2001. The new planning for results. Chicago: American Library Association.

Orr, Cynthia. 2003. Collection development in public libraries. In Encyclopedia of library and information science, edited by Miriam A. Drake, 585-590. 2d ed. New York, N.Y.: M. Dekker. 
Reitz, Joan M. 2002. ODLIS: Online dictionary of library and information science. http://www.wcsu.edu/library.odlis.html [Accessed 9 August 2003]

Rice-Lively, Mary Lynn. 1997. Analysing qualitative data from information organizations. In Qualitative research for the information professional: A practical handbook, G.E. Gorman and Peter Clayton, 198-221. London: Library Association.

Riley, Grant Russell. 1997. The National Library of New Zealand collection development policy: Strategic or circulation based approach? Wellington: Victoria University of Wellington.

Slyfield, Helen. 2001. Developments in public library services. [Wellington, N.Z.]: Research Unit, National Library.

Standards for New Zealand public libraries. 2002. Public Libraries Special Interest Group, Library and Information Association of New Zealand Aotearoa. http://www.lianza.org.nz/standards02.shtml [Accessed 2 August 2003]

Stephens, Annabel K. 1995. Assessing the public library planning process. Norwood, N.J.: Ablex Publishing Corporation.

Stephens, Annabel K. 1998. The public library planning process: Its impact on collection development policies and practices. Acquisitions Librarian 20: 15-23.

Stephens, Annabel K. 2003. Citizen participation in public libraries. In Encyclopedia of library and information science, edited by Miriam A. Drake, 531-545. 2d ed. New York, N.Y.: M. Dekker.

Submission on the Local Government Bill 2001. 2002. Library and Information Association of New Zealand Aotearoa. http://www.lianza.org.nz/submission-lga2.htm [Accessed 2 August 2003]

Thorsen, Jeanne. 1998. Community studies: Raising the roof and other recommendations. Acquisitions Librarian 20: 5-13.

Westbrook, Lynn. 2000. Analyzing community information needs: A holistic approach. Library Administration \& Management 14 (1): 26-30.

Wilson, Marion. 2000. Understanding the needs of tomorrow's library user: Rethinking library services for the new age. Australasian Public Libraries and Information Services 13 (2): 81-86. 


\section{Appendix A: Council websites}

Horowhenua District Council. 2002. Last modified Tuesday September 2003. http://www.horowhenua.govt.nz/ [Accessed 29 September 2003]

Hutt City. Website last updated September 2003. http://www.huttcity.govt.nz/ [Accessed 29 September 2003]

Manawatu District Council. 2003. http://www.mdc.govt.nz/ [Accessed 29 September 2003]

Palmerston North City Council. 2002. http: www.pncc.govt.nz/ [Accessed 16 November 2003]

Porirua City Council. 2002. http://www.pcc.govt.nz/ [Accessed 29 September 2003]

Wanganui District Council. Site content last updated on 14/11/03.

http://www.wanganui.govt.nz [Accessed 16 November 2003] 


\section{Appendix B: Participant information letter}

9 February 2004

\section{Dear}

I am a Masters student in Library \& Information studies at Victoria University of Wellington. As part of this degree, I am undertaking a research project. This project is to investigate public librarians' use of consultative processes during the formulation and application of collection development policies. The University requires that ethics approval be obtained for research involving human participants.

I am inviting public library managers in the Wanganui/Manawatu and Wellington regions to participate in this study. The library managers will be asked to participate in an interview, conducted at their place of work.

It is envisaged that the interview will be of approximately one hour's duration. The interview will be taped and transcribed. Participants will have the opportunity to read their interview transcription, in order to correct errors in the actual transcription.

Should any participants feel the need to withdraw from the project, they may do so without question at any time before the data is analysed, i.e. before 12 January 2004.

Responses collected will form the basis of my research project and will be put into a written report. It will not be possible for you to be identified personally in this report. All material will be kept confidential. No other person besides myself, my supervisor, Dr Gary Gorman, and the person who transcribes the tape recording will see the interview transcripts. The completed research project will be submitted to the supervisor for assessment and deposited in the University Library. The tape recordings will be electronically wiped at the end of the project. The interview transcripts will be retained, but in anonymous form, with no names identifying the interviewee or institution. The anonymous data from the study may be used again for a follow-up study of policy development and implementation to be conducted by the School of Information Management.

If you have any questions or would like to receive further information about this project, please contact me by phone, 04293 5572, or by email, sarah.osborne@xtra.co.nz, or my supervisor, Professor Gary Gorman, at the School of Information Management at Victoria University, phone: 04463 5783, or 021726736 (mobile), or email: gary.gorman@vuw.ac.nz.

Yours sincerely

Sarah Osborne 


\title{
Appendix C: Participant consent form
}

\author{
VICTORIA UNIVERSITY OF WELLINGTON \\ CONSENT TO PARTICIPATION IN RESEARCH
}

Title of project: Consulting the community: How customer needs are reflected in public library collection development policies.

I have been given and have understood an explanation of this research project. I have had an opportunity to ask questions and have them answered to my satisfaction. I understand that I may withdraw myself (or any information I have provided) from this project (before data collection and analysis is complete i.e. before 12 January 2004) without having to give reasons or without penalty of any sort.

I understand that any information I provide will be kept confidential to the researcher, the supervisor and the person who transcribes the tape recording of our interview. I understand that I will have an opportunity to read and correct the transcript of the interview. I understand that the published results will not use my name or the name of the library or institution, and that no opinions will be attributed to me in any way that will identify me. I understand that, at the end of the project, the tape recording of the interview will be electronically wiped. I understand that the anonymous data from the study may be used again for a follow-up study of policy development and implementation to be conducted by the School of Information Management.

$\square \quad$ I agree to take part in this research.

$\square \quad$ I would like to receive a summary of the results of this research when it is completed.

Signed:

Date:

Name of participant:

Postal address (for receipt of research summary): 


\section{Appendix D: Schedule of interviews}

\section{$\underline{\text { Pilot Study }}$}

\begin{tabular}{|l|l|}
\hline \multicolumn{1}{|c|}{ Date \& Time } & \multicolumn{1}{|c|}{ Participant } \\
\hline Tuesday 9 December & Andrew Peacocke \\
$\mathbf{1 1 . 3 0}$ am. & Support Services Manager \\
& Hutt City Libraries \\
& P.O. Box 30-037 \\
& Lower Hutt \\
& Phone: 045706633 \\
\hline
\end{tabular}

\section{Interview Schedule}

\begin{tabular}{|l|l|}
\hline \multicolumn{1}{|c|}{ Date \& Time } & \multicolumn{1}{c|}{ Participant } \\
\hline $\begin{array}{l}\text { Friday 12 December } \\
\mathbf{1 0 . 3 0} \text { am. }\end{array}$ & $\begin{array}{l}\text { Brian Anderson } \\
\text { Library Manager } \\
\text { Porirua City Library } \\
\text { P.O. Box 50-218 } \\
\text { Porirua City }\end{array}$ \\
& Phone: 04 237 1533 \\
\hline $\begin{array}{l}\text { Monday 15 December } \\
\text { Pam. }\end{array}$ & $\begin{array}{l}\text { Sally Patrick } \\
\text { Manager } \\
\text { Wanganui District Library } \\
\text { Private Bag 3005 } \\
\text { Wanganui }\end{array}$ \\
& Phone: 06 349 1000 \\
\hline Thursday 18 December & Simon Johnson \\
9.30 am. & District Librarian \\
& Feilding Public Library \\
& P.O. Box 264 \\
& Feilding \\
& Phone: 06 323 5373 \\
\hline
\end{tabular}




\begin{tabular}{|l|l|}
\hline $\begin{array}{l}\text { Thursday } 18 \text { December } \\
\mathbf{1 . 0 0} .\end{array}$ & $\begin{array}{l}\text { Lynette Collis } \\
\text { Head of Advisory Services } \\
\text { Palmerston North City Library } \\
\text { P.O. Box 1948 } \\
\text { Palmerston North } \\
\text { Phone: } 063514100\end{array}$ \\
\hline $\begin{array}{l}\text { Monday 22 December } \\
\mathbf{1 0 . 3 0} \text { am. }\end{array}$ & $\begin{array}{l}\text { Rosalie Blake } \\
\text { Head of Libraries } \\
\text { Horowhenua Public Libraries } \\
10 \text { Bath Street } \\
\text { Levin }\end{array}$ \\
& Phone: 063681953 \\
\hline
\end{tabular}


Appendix E: Thematic coding list

\section{CODING THEMES}

\begin{tabular}{|c|c|}
\hline \multicolumn{2}{|c|}{$\begin{array}{c}\text { A: Methods of obtaining information about community and customer needs } \\
\text { and wants }\end{array}$} \\
\hline \multicolumn{2}{|c|}{$\begin{array}{l}\text { (i) Consultation methods: Use of direct consultative methods that involve } \\
\text { interaction with customers and the community }\end{array}$} \\
\hline Coding Label & Theme \\
\hline Usu & User surveys \\
\hline Foc & Focus groups \\
\hline Com & Formal committees eg. Friends of the library, library trustees \\
\hline CoI-sch & Liaison with community institutions - schools \\
\hline CoI-ter & Liaison with community institutions - tertiary education providers \\
\hline CoG & $\begin{array}{l}\text { Liaison with community groups, including ethnic groups and } \\
\text { special interest groups }\end{array}$ \\
\hline Bic & Liaison with Maori \\
\hline Sta & Staff feedback \\
\hline Cop & $\begin{array}{l}\text { Library comments and complaints procedures, both formal and } \\
\text { informal }\end{array}$ \\
\hline Obs & $\begin{array}{l}\text { Observations about customers and the community, based on the } \\
\text { professional experience and judgment of the library manager. }\end{array}$ \\
\hline \multicolumn{2}{|c|}{$\begin{array}{l}\text { (ii) Data-analysis methods: Indirect methods gathering of data from various } \\
\text { sources that don't involve direct contact with the community and customers }\end{array}$} \\
\hline Coding Label & Theme \\
\hline Cen & Census data \\
\hline Cou & Council-initiated data-gathering activities and planning activities \\
\hline Sur & Surveys conducted by outside organizations \\
\hline Res & Use of research consultants \\
\hline Cir & Analysis of materials circulation data \\
\hline Bor & Analysis of borrower activity data \\
\hline Gat & Gate-counts \\
\hline Inh & Analysis of in-house materials use \\
\hline $\operatorname{Req}$ & Analysis of requested materials \\
\hline
\end{tabular}




\begin{tabular}{|c|l|}
\hline Coding Label & The following sub-themes are applied to the methods listed above \\
\hline /Pur & Purpose ie. the reasons why particular methods are used \\
\hline /Adv & Advantages or benefits of the method \\
\hline /Dis & Disadvantages or drawbacks of the method \\
\hline /Fre & $\begin{array}{l}\text { Frequency of usage of the method, and description of how it is } \\
\text { carried out }\end{array}$ \\
\hline /Rol & $\begin{array}{l}\text { Role of the method ie. how the information gathered is used in the } \\
\text { formulation and application of collection development policies. }\end{array}$ \\
\hline
\end{tabular}

\begin{tabular}{|c|c|}
\hline \multicolumn{2}{|c|}{ B: Collection development policies } \\
\hline Coding Label & Theme \\
\hline $\mathbf{c d p} / \mathbf{F}$ & Formal, written collection development policy document \\
\hline \multirow[t]{2}{*}{$\mathrm{cdp} / \mathrm{I}$} & Informal or unwritten policies, practices, procedures \\
\hline & $\begin{array}{c}\text { Sub-themes } \\
\text { The following sub-themes are applied to the policies listed above }\end{array}$ \\
\hline$/$ Imp & Discussion about the importance of a written policy document \\
\hline /Fun & Function ie. the uses to which the policy is put within the institution \\
\hline /Adv & Advantages or benefits of that particular type of policy \\
\hline /Dis & Disadvantages or drawbacks of that particular type of policy \\
\hline /Fre & $\begin{array}{l}\text { Frequency of revision of the policies, including discussion of who is } \\
\text { involved in formulating them }\end{array}$ \\
\hline /Sel & $\begin{array}{l}\text { Discussion about how the policies are applied to materials selection } \\
\text { activities. }\end{array}$ \\
\hline /Rol & $\begin{array}{l}\text { Discussion about the link between community consultation/data } \\
\text { gathering and policy formulation and application. }\end{array}$ \\
\hline
\end{tabular}


Appendix F: Data analysis charts

Chart 1: Analysis of information-gathering methods

\begin{tabular}{|c|l|l|l|l|l|}
\hline & Purpose & Advantages & Disadvantages & Frequency & Role \\
\hline (i) Direct methods & & & & & \\
\hline & & & & & \\
\hline $\boldsymbol{1}$ & & & & & \\
\hline $\begin{array}{l}\text { (ii) Indirect } \\
\text { methods }\end{array}$ & & & & & \\
\hline & & & & & \\
\hline & & & & & \\
\hline & & & & & \\
\hline
\end{tabular}

Chart 2: Comparison of information-gathering methods

\begin{tabular}{|l|l|l|}
\hline & $\begin{array}{c}\text { Community consultation } \\
\text { methods }\end{array}$ & Data-analysis methods \\
\hline Purpose & & \\
\hline Advantages & & \\
\hline Disadvantages & & \\
\hline Frequency & & \\
\hline Role & & \\
\hline
\end{tabular}

Chart 3: Analysis of collection development policies

\begin{tabular}{|l|l|l|}
\hline & \multicolumn{1}{|c|}{ Informal policies } & Formal policies \\
\hline Importance & & \\
\hline Function & & \\
\hline Advantages & & \\
\hline Disadvantages & & \\
\hline Frequency & & \\
\hline Selection & & \\
\hline Role & & \\
\hline
\end{tabular}


Chart 4: Summary of the relationships between information-gathering methods and collection development policies

\begin{tabular}{|c|l|l|}
\hline $\begin{array}{l}\text { Method of } \\
\text { obtaining } \\
\text { information }\end{array}$ & $\begin{array}{l}\text { What community/customer needs } \\
\text { does this method help to identify? }\end{array}$ & $\begin{array}{l}\text { What role does this method play } \\
\text { in library collection development } \\
\text { policies? }\end{array}$ \\
\hline & & \\
\hline & & \\
\hline & & \\
\hline & & \\
\hline & & \\
\hline
\end{tabular}




\section{Appendix G: Sample survey questionnaire}

\section{"Consulting the community..."}

(To be administered to public libraries serving populations of between 30,000 and $70,000)$.

1. Does the library have a formal, written collection development policy?

2. If so, when was this policy last revised?

3. Is so, which of the following roles [list roles] does the policy fulfill in your institution?

4. Does the library have a written document, or documents, outlining collection management practices and procedures?

5. If so, how frequently are these documents revised?

6. Which of the following community consultation techniques have been used by the library in the last five years [list techniques]?

7. Please describe how use of these techniques contributes to collection development activities?

8. What do you feel are (a) the benefits, and (b) the disadvantages of community consultation techniques?

9. Which of the following data analysis techniques are regularly used by the library [list techniques]?

10. Please describe how these techniques contribute to collection development activities?

11. Which methodologies do you feel provide the most useful information about your community and your customers' needs: (a) community consultation, or (b) data analysis? Please explain why. 